\title{
Plant Acyl-CoA-Binding Proteins-Their Lipid and Protein Interactors in Abiotic and Biotic Stresses
}

\author{
Sze-Han Lai and Mee-Len Chye *(D) \\ School of Biological Sciences, The University of Hong Kong, Pokfulam, Hong Kong, China; \\ szehan1@connect.hku.hk \\ * Correspondence: mlchye@hku.hk; Tel.: +852-22990319
}

Citation: Lai, S.-H.; Chye, M.-L.

Plant Acyl-CoA-Binding

Proteins-Their Lipid and Protein Interactors in Abiotic and Biotic

Stresses. Cells 2021, 10, 1064. https://

doi.org/10.3390/cells10051064

Academic Editors: Éric Maréchal and Rebecca Roston

Received: 29 March 2021

Accepted: 27 April 2021

Published: 30 April 2021

Publisher's Note: MDPI stays neutral with regard to jurisdictional claims in published maps and institutional affiliations.

\begin{abstract}
Plants are constantly exposed to environmental stresses during their growth and development. Owing to their immobility, plants possess stress-sensing abilities and adaptive responses to cope with the abiotic and biotic stresses caused by extreme temperatures, drought, flooding, salinity, heavy metals and pathogens. Acyl-CoA-binding proteins (ACBPs), a family of conserved proteins among prokaryotes and eukaryotes, bind to a variety of acyl-CoA esters with different affinities and play a role in the transport and maintenance of subcellular acyl-CoA pools. In plants, studies have revealed ACBP functions in development and stress responses through their interactions with lipids and protein partners. This review summarises the roles of plant ACBPs and their lipid and protein interactors in abiotic and biotic stress responses.
\end{abstract}

Keywords: abiotic stress; acyl-CoA-binding proteins; biotic stress; lipids; protein interactors; stress signalling

\section{Introduction}

Lipids are crucial components in facilitating developmental and adaptation processes in all prokaryotes and eukaryotes. They form the primary structure of cell membranes, maintaining cellular fluidity and integrity, and provide energy during plant growth and development, including germination, organ differentiation and pollination [1-3]. Moreover, seed and seedling development require energy fuelled by lipids in the form of triacylglycerols (TAGs) [4-6]. Lipids also contribute to processes such as the establishment and maintenance of cellular polarity, and chlorophyll and carotenoid production in photosynthesis [7-10]. Previous studies have proven that plant lipids act as signal transducers in signalling pathways essential to development and responses in both biotic and abiotic stresses caused by pathogens, extreme temperatures, flooding, salinity, heavy metals, osmotic damage and wounding [11-18]. For instance, the rapid formation of aldehydes and alcohols from fatty acid (FA) hydroperoxides occurs upon wounding [19]. These derivatives from oxylipins can protect plants from fungal and insect attacks, and drive the expression of abiotic stress-associated genes [19]. Jasmonate (JA), a major phytohormone, can appear in several active forms including methyl JA (MeJA) and cis-jasmone, and these active metabolites act as signalling molecules, activating plant defensive genes when exposed to biotic and abiotic stresses [20]. Phosphatidic acid (PA), a minor class of glycerophospholipids, is a versatile lipid mediator that exhibits dynamic changes upon perceiving stress signals [21]. PA can modulate signalling and cellular processes through protein interactions that can cause several structural effects on target proteins such as membrane tethering, conformational change, competitive ligand binding and oligomerization [21]. Furthermore, epidermal lipids such as cutin, suberin and waxes, form physical barriers to control water loss and protect the plant against environmental threats [22-29].

There are eight categories of lipids, including fatty acyls, glycerolipids, glycerophospholipids, sphingolipids, saccharolipids, polyketides, sterol lipids and prenol lipids [30]. Glycerolipids, sphingolipids and sterols are the primary constituents of plant membranes [31]. 
In plants, de novo biosynthesis of lipids takes place in the plastids and endoplasmic reticulum (ER) [32]. Some of the acyl chains produced in the plastids [33] are used for galactolipid biosynthesis (the prokaryotic pathway), while the majority are transported to the ER for glycerolipid and extraplastidial membrane lipid biosynthesis (the eukaryotic pathway) [32,34]. In the ER, glycerol-3-phosphate is acylated with acyl-CoA exported from the plastids to generate PA $[35,36]$. PA can be converted to cytidyldiphosphate-diacylglycerol (CDP-DAG) by CDP-DAG synthase and subsequently to phosphatidylglycerol (PG) and phosphatidylinositol (PI) [37]. Alternatively, the dephosphorylation of PA to DAG can lead to the synthesis of phosphatidylcholine (PC), phosphatidylethanolamine (PE) and phosphatidylserine (PS) [37]. Phospholipids consist of a hydrophilic head containing a phosphate group and glycerol and two FA tails [38]. They form the main structural components of membranes, and are recognized as second messengers $[39,40]$ in regulating plant growth and development, as well as cellular responses to environment or stress [41,42]. Many studies have shown that plants respond via phospholipid signalling to stress stimuli from salt, osmotic damage, temperature changes as well as pathogens [40,43-47].

Sphingolipids, a diverse class of lipids, constitute many structural combinations of sphingoid bases, the $\mathrm{N}$-acylated fatty acid and the polar head group [48]. They can form complex sphingolipids in plants through the hydroxylation or desaturation of long-chain base (LCB) components and fatty acid chains [49]. The LCB and the ceramide can be present as phosphorylated or nonphosphorylated forms [50]. Plant sphingolipids are divided into four main classes namely ceramides, glycosylceramides (GlcCers), glycosylinositolphosphoceramides (GIPCs) and free LCBs, with GIPCs predominating in plant tissues [51]. Sphingolipids, well-studied in animal systems, have been implicated in many essential processes in plants including pollen development, signal transduction and responses to biotic and abiotic stresses [52].

Sterols are isoprenoids, and are another important integral membrane component having diverse functions in all eukaryotes [49]. Sterols regulate acyl chain ordering and, together with glycerolipids and sphingolipids, they reinforce the structure of cell membranes [53,54]. In addition, some sterols form special structures with sphingolipids known as microdomains or lipid rafts $[55,56]$. These structures regulate important processes such as signal transduction, protein trafficking and plant-pathogen interactions [54,57]. Plant sterols are mainly comprised of campesterol, stigmasterol, $\beta$-sitosterol and brassicasterol $[49,58]$. With exposure to abiotic stresses such as ultraviolet (UV) radiation, low temperature and drought, marked changes in sterol content are observed, indicating that sterols may regulate plant response to stresses by maintaining membrane stability [59-62]. In grapes, low-intensity UV induced the acclimation response to repair damaged membranes following sterol synthesis, whereas high-intensity UV triggered antioxidant production to counteract oxidative damage [60]. Cold stress, on the other hand, causes changes in lipid content and membrane fluidity, thus improving the mechanical adaption of plants to low temperature [61]. In dehydrated plants, an increase in steryl ester levels may be associated with membrane lipid metabolism to maintain membrane integrity [62].

Acyl-CoA-binding proteins (ACBPs) were first identified in rat brain as neuropeptides that prevent the binding of diazepam to the receptor of $\gamma$-aminobutyric acid (GABA) [63]. Diazepam is a benzodiazepine drug used in the treatment of anxiety disorders, muscle spasm, spasticity and alcohol detoxification [64]. It binds to the GABA receptor and causes the neuronal influx of chloride ions, thus decreasing the excitability of the neuron after hyperpolarisation of postsynaptic membranes [64]. Thus ACBP, also known as the diazepam-binding inhibitor, displaces diazepam from the GABA receptor binding site and suppresses the anxiolytic effects of diazepam or other benzodiazepines [65]. Later, ACBPs were discovered in other eukaryotes and some prokaryotes [66,67]. ACBPs bind to a variety of acyl-CoA esters with different affinities, implying that they play a role in the transport and maintenance of the acyl-CoA pool. ACBPs can recruit long-chain acyl-CoAs immobilised in multilamellar liposomes and form acyl-CoA/ACBP complexes [68]. Such complexes can then transport and donate acyl-CoAs to mitochondrial $\beta$-oxidation and 
microsomal glycerolipid synthesis [68]. When ACBPs are available in equimolar, or in excess, to long-chain acyl-CoAs, ACBP can sequester the synthesised acyl-CoA esters and prevent the inhibition of both acetyl-CoA carboxylase and the mitochondrial adenine nucleotide translocase caused by long-chain acyl-CoAs [69]. Hence, long-chain acyl-CoAs are protected from microsomal acyl-CoA hydrolases [69].

In yeast, reduction of ACBP levels coincides with differential gene expression of fatty acid and phospholipid biosynthesis, glycolysis and glycerol metabolism, and stress responses [70]. Roundworm (Caenorhabditis elegans) expresses seven ACBPs, and depletion of ACBP-1, ACBP-2 or ACBP-3 affects $\beta$-oxidation of fatty acids and intestinal lipid storage, indicating that ACBPs are important for lipid metabolism and storage in C. elegans [71]. The C. elegans acbp-1 knockout mutant can mobilise lipid stores and increase fatty acid oxidation to a level similar to the wild type under starvation [71]. Knockdown of the C. elegans membrane-associated ACBP 1 (MAA-1) extended lifespan and improved resistance to heat and oxidative stresses, mediated by transcriptional regulator encoding a hypoxia inducible factor (HIF-1) [72]. Aging-induced proteotoxicity was also improved by the HIF-1 transcriptional activation of small heat-shock proteins (sHSPs), leading to longevity in maa-1 mutants [72]. The stress responses caused by heat stress and oxidation in C. elegans maa-1 mutants require further investigation. Moreover, an increasing number of studies on plant ACBPs have shown that ACBPs play different roles in development and stress responses by interacting with lipids and protein partners [73-82]. This review gathers current knowledge on the regulatory roles of plant ACBPs, together with lipids, in response to abiotic and biotic stresses.

\section{Plant ACBPs}

Plant ACBPs were first identified in Brassica napus L. (oilseed rape) as a 10-kDa homologue expressed in seeds, flowers and cotyledons [66]. It binds long-chain acylCoA esters [83], participates in acyl-CoA transport [84], maintains acyl-CoA pool [85], and regulates the activities of various enzymes including glycerol-3-phosphate acyltransferase [83], lysophosphatidylcholine acyltransferase [85] and lysophosphatidic acid acyltransferase [86]. The transport of acyl-CoA esters is important for the biosynthesis of lipids such as glycerolipids, ceramides and phospholipids, and studies have shown that the binding of phospholipids to ACBPs plays a role in plant growth and development as well as stress responses [76,78,87-94]. Following the discovery of BnACBP, similar 10-kDa ACBPs emerged in Arabidopsis thaliana [95], Gossypium hirsutum (cotton) [96], Ricinus communis (castor bean) [97], Digitalis lanata Ehrh. (Wolly Foxglove) [98], Oryza sativa (rice) [89], Vernicia fordii (tung tree) [99], Vitis vinifera (grape) [100], Helianthus annuus (sunflower) [101], Elaeis guineensis (oil palm) [102], Zea mays (maize) [103] and Glycine max (soybean) [104].

In plants such as Arabidopsis, rice, oilseed rape, oil palm, maize and soybean, ACBPs are classified into four main groups according to size and domains: Class I small ACBPs, Class II ACBPs containing ankyrin repeats, Class III large ACBPs and Class IV ACBPs containing kelch motifs (Table 1) [89,102-105]. Table 1 shows that Class I ACBPs range from 10 to $17 \mathrm{kDa}$, whereas the others comprised of a transmembrane domain, ankyrin repeats and/or kelch motifs, have molecular weights of 34 to $85 \mathrm{kDa}[89,103]$. Arabidopsis ACBPs are localised to the ER and plasma membrane (AtACBP1 and AtACBP2) [106,107], apoplast (AtACBP3) [108] and cytosol (AtACBP4 to AtACBP6) [87,109]. On the other hand, rice ACBPs are subcellularly localised to the cytosol (OsACBP1 to OsACBP3) [91], ER (OsACBP4) [91,110], apoplast (OsACBP5) [111] and peroxisomes (OsACBP6) [91]. In maize, transient expression of green fluorescent protein (GFP)-tagged Class I ZmACBP1 in Nicotiana benthamiana leaf epidermal cells revealed that ZmACBP1 was confined to the cytosol, Class II ZmACBP3 localised to the ER, whereas Class III and IV ZmACBP6 and ZmACBP7, respectively, were targeted to both the cytosol and the plasma membrane [103]. Oil palm Class II EgACBP2 contains an $N$-terminal transmembrane domain responsible for protein targeting to the plasma membrane, and two $C$-terminal ankyrin repeats which could mediate protein-protein interactions and other cellular activities [102]. Consistent 
with Protein Subcellular Localization Prediction Tool (PSORT) speculation, the sunflower Class I HaACBP6, which was transiently expressed in tobacco leaves, was localised to the cytosol and nucleus [101]. These results are summarised in Table 1.

Table 1. Characterization of plant ACBPs.

\begin{tabular}{|c|c|c|c|c|c|c|c|c|}
\hline Class & $\begin{array}{l}\text { Protein } \\
\text { Name }\end{array}$ & $\begin{array}{l}\text { Signal } \\
\text { Peptide }\end{array}$ & $\begin{array}{c}\text { TM } \\
\text { Domain }\end{array}$ & $\begin{array}{c}\text { ACB } \\
\text { Domain }\end{array}$ & $\begin{array}{l}\text { Ankyrin } \\
\text { Repeats }\end{array}$ & $\begin{array}{l}\text { Kelch } \\
\text { Motifs }\end{array}$ & $\begin{array}{l}\text { Subcellular } \\
\text { Locations }\end{array}$ & Size (kDa) \\
\hline \multirow{6}{*}{ I } & AtACBP6 & - & - & + & - & - & Cytosol & 10.4 \\
\hline & OsACBP1 & - & - & + & - & - & Cytosol & 10.2 \\
\hline & OsACBP2 & - & - & + & - & - & Cytosol & 10.3 \\
\hline & OsACBP3 & - & - & + & - & - & Cytosol & 17.7 \\
\hline & $\mathrm{ZmACBP1}$ & - & - & + & - & - & Cytosol & 10.1 \\
\hline & НаAСВР6 & - & - & + & - & - & $\begin{array}{l}\text { Cytosol, } \\
\text { Nucleus }\end{array}$ & 10.9 \\
\hline \multirow{5}{*}{ II } & AtACBP1 & - & + & + & + & - & ER, PM & 37.5 \\
\hline & AtACBP2 & - & + & + & + & - & ER, PM & 38.5 \\
\hline & OsACBP4 & + & + & + & + & - & ER & 36 \\
\hline & $\mathrm{ZmACBP3}$ & - & - & + & + & - & ER & 34.8 \\
\hline & EgACBP2 & - & + & + & + & - & PM & ND \\
\hline \multirow{3}{*}{ III } & AtACBP3 & + & + & + & - & - & Apoplast & 39.3 \\
\hline & OsACBP5 & + & + & + & - & - & ER & 61.2 \\
\hline & ZmACBP6 & - & - & + & - & - & Cytosol, PM & 35.2 \\
\hline \multirow{4}{*}{ IV } & AtACBP4 & - & - & + & - & + & Cytosol & 73.2 \\
\hline & AtACBP5 & - & - & + & - & + & Cytosol & 71 \\
\hline & OsACBP6 & - & + & + & - & + & Peroxisomes & 71.4 \\
\hline & ZmACBP7 & - & - & + & - & + & Cytosol, PM & 72.1 \\
\hline
\end{tabular}

Abbreviations: ACB, acyl-CoA-binding; ACBP, acyl-CoA-binding protein; At, Arabidopsis thaliana; Eg, Elaeis guineensis; ER, endoplasmic reticulum; Ha, Helianthus annuus; $\mathrm{kDa}$, kilodalton; ND, not determined; Os, Oryza sativa; PM, plasma membrane; TM, transmembrane; Zm, Zea mays; -, absent; +, present.

Using isothermal titration calorimetry (ITC), it has been reported that all recombinant ACBPs (rACBPs) bind acyl-CoA esters with varying affinities; rAtACBP1 and rAtACBP3 displayed high affinity to very-long-chain (VLC) species $[26,108,112]$, while rAtACBP3 to rAtACBP6 and rOsACBPs to medium-chain species $[89,113]$. All rAtACBPs and rOsACBPs bind long-chain acyl-CoA esters at different affinities [75,89,94,108,114,115]. Moreover, rACBPs were shown to bind phospholipids, all Arabidopsis rAtACBPs bind PC $[78,87,112,115,116]$, and rAtACBP1, rAtACBP2 and rAtACBP3 bind PA, lysoPC, and $\mathrm{PE}$, respectively $[76,88,112,117]$. In contrast, all rice rOsACBPs bind PA and PC [89]. Besides binding with high affinity to 16:0-CoA, 18:0-CoA and 18:1-CoA, sunflower Class I rHaACBP6 and Class II rHaACBP1 also bind to several PC species [101,118]. In addition to phospholipid binding, Arabidopsis ACBPs were shown to interact with protein interactors (Table 2). AtACBPs interact with various transcription factors that activate the gene expression for downstream abscisic acid (ABA) or ethylene responses upon perception of stress stimuli $[73,77,80]$. These transcription factors include ABA-RESPONSIVE ELEMENT BINDING PROTEIN1 (AREB1) [80], RELATED TO APETALA2.12 (RAP2.12) [77] and ETHYLENE-RESPONSIVE ELEMENT BINDING PROTEIN (AtEBP) [73]. Furthermore, AtACBPs bind enzymes for sterol or phospholipid metabolisms such as PHOSPHOLIPASE $\mathrm{D} \alpha 1$ (PLD $\alpha 1$ ) [78], STEROL C4-METHYL OXIDASE1-1 (SMO1-1) [119], SMO1-2 [81] and LYSOPHOSPHOLIPASE2 (LYSOPL2) [76,82], which are important for membrane stability and repair as well as plant development. Thus far, only AtACBP2 interacts with FARNESYLATED PROTEIN6 (AtFP6) which may be involved in phospholipid repair following heavy metal-induced lipid peroxidation [75]. Lipid binding of ACBPs and their protein-protein interactions are now known to be important in regulating abiotic and biotic stress responses $[74-76,78,80,87,88,93,120-128]$, as well as plant development including embryoge- 
nesis [81,116,119], seed dormancy [78], seed germination and development [78,80,129-131], cuticle development $[25,26]$, pollen growth [132] and senescence [112,117].

Table 2. Abiotic and biotic stress responses mediated by plant ACBPs and/or their interactors.

\begin{tabular}{|c|c|c|c|c|c|}
\hline Proteins & Species & Acyl-CoA Binding & $\begin{array}{l}\text { Phospholipid } \\
\text { Binding }\end{array}$ & $\begin{array}{c}\text { Protein } \\
\text { Interactors }\end{array}$ & Stress Responses \\
\hline \multirow{6}{*}{ AtACBP1 } & \multirow{6}{*}{ A. thaliana } & \multirow{6}{*}{$\begin{array}{c}16: 0,18: 1,18: 2,18: 3 \\
20: 4,24: 0,25: 0,26: 0 \\
{[26,108,133]}\end{array}$} & \multirow{6}{*}{$\begin{array}{l}\text { PC [78] } \\
\text { PA [88] }\end{array}$} & PLD $\alpha 1$ [78] & Freezing [88] \\
\hline & & & & $\begin{array}{c}\text { RAP2.12 } \\
{[77,128,134]}\end{array}$ & Hypoxia $[77,128]$ \\
\hline & & & & {$[17,120,10 \pm]$} & Salinity, osmotic \\
\hline & & & & AREB1 [80] & damage [80] \\
\hline & & & & - & Heavy metal [135] \\
\hline & & & & - & Pathogen [26] \\
\hline \multirow{5}{*}{ AtACBP2 } & \multirow{5}{*}{ A. thaliana } & \multirow{5}{*}{$\begin{array}{c}16: 0,18: 1,18: 2,18: 3 \\
20: 4[75,108,114]\end{array}$} & \multirow{5}{*}{$\begin{array}{c}\text { PC [116] } \\
\text { lysoPC [76] }\end{array}$} & $\begin{array}{c}\text { AtEBP [73], } \\
\text { RAP2.12 }[77,128]\end{array}$ & Hypoxia $[73,77]$ \\
\hline & & & & $\begin{array}{c}\text { LYSOPL2 }[76,82], \\
\text { AtFP6 }[75]\end{array}$ & $\begin{array}{c}\text { Heavy metal } \\
{[75,76,82]}\end{array}$ \\
\hline & & & & - & Drought [90] \\
\hline & & & & - & Salinity [94] \\
\hline & & & & - & Oxidation [75] \\
\hline \multirow{4}{*}{ AtACBP3 } & \multirow{4}{*}{ A. thaliana } & \multirow{4}{*}{$\begin{array}{c}12: 0,14: 0,16: 0,18: 1 \\
18: 2,18: 3,20: 4,22: 0 \\
24: 0[108,112,126,136]\end{array}$} & \multirow{4}{*}{$\begin{array}{c}\text { PC [112] } \\
\text { PE [112,117] }\end{array}$} & - & Drought [25] \\
\hline & & & & - & Hypoxia $[136,137]$ \\
\hline & & & & - & Wounding [126] \\
\hline & & & & - & $\begin{array}{l}\text { Pathogen } \\
{[25,108,121]}\end{array}$ \\
\hline \multirow{3}{*}{ AtACBP4 } & \multirow{3}{*}{ A. thaliana } & \multirow{3}{*}{$\begin{array}{c}14: 0,16: 0,18: 0,18: 1 \\
18: 2,18: 3[113,115]\end{array}$} & \multirow{3}{*}{ PC [115] } & AtEBP [74] & Pathogen $[25,74]$ \\
\hline & & & & - & Drought [25] \\
\hline & & & & - & Heavy metal [124] \\
\hline \multirow{4}{*}{ AtACBP6 } & \multirow{4}{*}{ A. thaliana } & \multirow{4}{*}{$\begin{array}{c}14: 0,16: 0,18: 0,18: 1 \\
18: 2,18: 3,20: 4 \\
{[95,113,115]}\end{array}$} & \multirow{4}{*}{ PC [87] } & - & Freezing $[87,123]$ \\
\hline & & & & - & Drought [25] \\
\hline & & & & - & Wounding [125] \\
\hline & & & & - & Pathogen [25] \\
\hline OsACBP4 & O. sativa & $\begin{array}{c}16: 0,18: 0,18: 1,18: 2 \\
18: 3[89,94]\end{array}$ & PC, PA [91] & - & Salinity $[89,94]$ \\
\hline \multirow{2}{*}{ OsACBP5 } & \multirow{2}{*}{ O. sativa } & \multirow{2}{*}{$16: 0,18: 3[89,93]$} & \multirow{2}{*}{ PC, PA [91] } & - & Pathogen \\
\hline & & & & - & Wounding [89] \\
\hline OsACBP6 & O. sativa & $18: 1,18: 2$ [89] & PC, PA [91] & - & Wounding [89] \\
\hline ZmACBP1 & Z. mays & - & - & - & $\begin{array}{l}\text { Salinity, drought } \\
\text { [103] }\end{array}$ \\
\hline $\mathrm{ZmACBP3}$ & Z. mays & - & - & - & $\begin{array}{l}\text { Salinity, drought } \\
\text { [103] }\end{array}$ \\
\hline ChACBP1 & Chlorella sp. & - & PC [92] & - & $\begin{array}{l}\text { Freezing, salinity, } \\
\text { oxidation, heavy } \\
\text { metal [92] }\end{array}$ \\
\hline VvACBP & $V$. vinifera & - & - & - & $\begin{array}{c}\text { Freezing, heat, ER, } \\
\text { pathogen [100] }\end{array}$ \\
\hline
\end{tabular}

Abbreviations: AREB1, ABSCISIC ACID-RESPONSIVE ELEMENT BINDING PROTEIN1; AtEBP, Arabidopsis ETHYLENE-RESPONSIVE BINDING PROTEIN; AtFP6, Arabidopsis FARNESYLATED PROTEIN6; ER, endoplasmic reticulum; lysoPC, lysophosphatidylcholine; LYSOPL2, LYSOPHOSPHOLIPASE2; PA, phosphatidic acid; PC, phosphatidylcholine; PE, phosphatidylethanolamine; PLD $\alpha 1$, PHOSPHOLIPASE D $\alpha 1 ;$ RAP2.12, RELATED TO APETALA2.12. 


\section{Membrane Lipids and ACBPs in Abiotic Stress Signalling}

Plants are sessile, and therefore possess signalling and adaptive mechanisms to counteract abiotic and biotic stresses including cold, drought, salinity, oxidation, heavy metals, hypoxia and pathogen attack. Given the importance of plant ACBPs in development and stress responses, the roles of all Arabidopsis and rice ACBPs at different stages of plant growth were previously summarized by Du et al. [138] and are now updated (Table 2). Studies on the binding by ACBPs of acyl-CoA esters, membrane lipids and protein interactors have provided insights into the mechanistic events that occur when plants are exposed to various abiotic stresses (Figure 1).

\subsection{Cold Stress}

AtACBP6-overexpressing (AtACBP6-OE) transgenic Arabidopsis rosettes and flowers are freezing tolerant (Figure 1) $[87,123]$. Northern-blot and Western-blot analyses showed that the expression of AtACBP 6 and its protein in the wild type was induced at $48 \mathrm{~h}$ after $4{ }^{\circ} \mathrm{C}$ cold treatment [87]. The atacbp 6 mutant showed increased sensitivity to freezing temperature $\left(-8^{\circ} \mathrm{C}\right)$ in contrast to the AtACBP6-OE plants [87]. Lipid profiles of rosettes upon freezing treatment of AtACBP6-OE transgenic Arabidopsis recorded decreases in PC and increases in PA, over the wild-type plants [87]. Furthermore, in vitro filter-binding assays revealed that rAtACBP6 binds PC, but not PA or lysoPC, suggesting a role for AtACBP6 in phospholipid metabolism in Arabidopsis [87]. On the other hand, in transgenic Arabidopsis AtACBP6-OE flowers, PC and monogalactosyldiacylglycerol (MGDG) levels were elevated while PA decreased [123]. In AtACBP6-OE rosettes, PHOSPHOLIPASE $D \delta(P L D \delta)$ was upregulated in the absence of COLD-RESPONSIVE (COR)-related gene induction [87], while flowers showed increased expression of COR-related genes and their transcription factors (C-repeat binding factors (CBFs), INDUCER OF CBF EXPRESSION1 (ICE1) and MYB15), PC-related genes, MGDG-related genes and ABA-related genes [123]. These results suggest a differential mechanism of freezing tolerance conferred by AtACBP6 in rosettes and flowers, possibly mediated by soluble sugar and proline accumulation and the ABA signalling pathway, respectively (Figure 1) [123].

Besides Class I AtACBP6, Arabidopsis Class II AtACBP1 also plays a role in freezing tolerance (Figure 1) [88]. AtACBP1-OE transgenic Arabidopsis plants were more coldsensitive, accompanied by PC reduction and PA elevation, while atacbp 1 plants were better protected from freezing arising from an increase in PC and a reduction in PA [88]. Although AtACBP1 and AtACBP6 belong to the same protein family, they play distinctive roles in cold tolerance. In vitro binding of rAtACBP1 to PA indicated possible enhanced PA interaction in AtACBP1-OE plants [78,88]. PLD $\alpha 1$, an important enzyme that catalyses the conversion of PC to PA, showed a higher gene expression in AtACBP1-OE plants than in atacbp 1 [88]. In contrast, PLD $\delta$ expression decreased in the AtACBP1-OEs but increased in atacbp1 [88]. As AtACBP1 is localised to the ER and plasma membrane, it may maintain a membrane-associated PA pool through PA binding, thereby regulating the expression of PLD $\alpha 1$ and PLD $\delta$ [88].

Other than AtACBPs, grape $V v A C B P$ was upregulated in leaves upon cold and heat shock stresses in comparison to the nontreated control [100]. In maize, the expression levels of $Z m A C B P 2, Z m A C B P 3, Z m A C B P 5$ and $Z m A C B P 6$ were induced by cold stress while $\mathrm{Z} m A C B P 1, \mathrm{Z} m A C B P 4, \mathrm{Z} m A C B P 7, \mathrm{Z} m A C B P 8$ and $\mathrm{ZmACBP9}$ mRNA levels declined after cold treatment [103]. These changes in expression levels depicted the potential roles of $\mathrm{ZmACBPs}$ in cold stress response which remain to be further elucidated. RNA-seq data analysis of the expression of soybean GmACBPs showed that only Class IV GmACBP11 was downregulated at $24 \mathrm{~h}$ after cold stress, whereas other $G m A C B P s$ displayed a lack of significant changes of expression in comparison to the nontreated control [104]. 

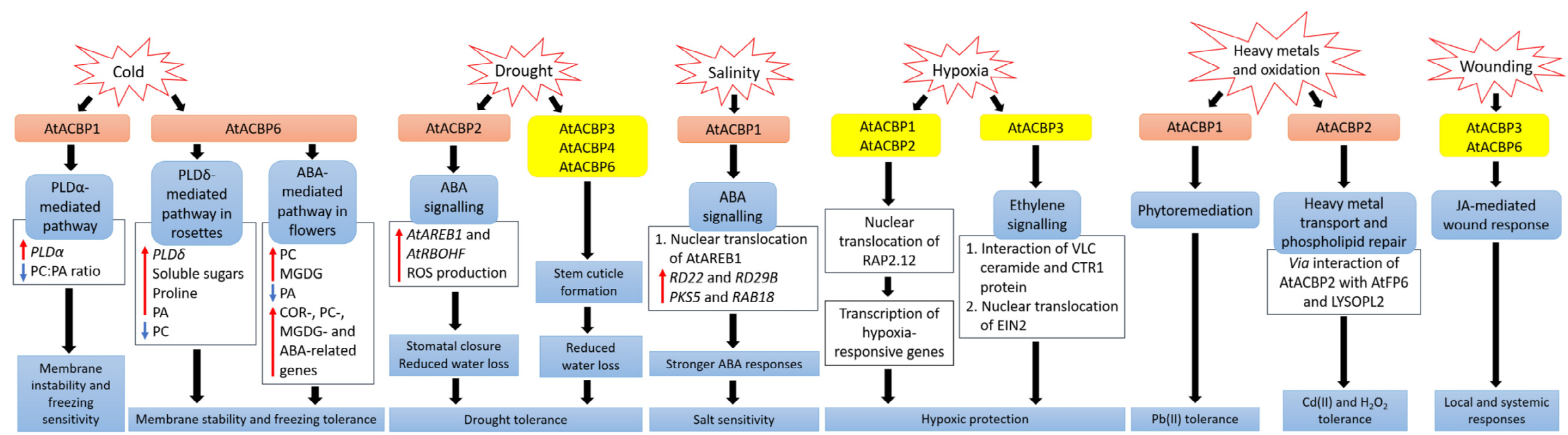

Figure 1. Signalling pathways associated with acyl-CoA-binding proteins (ACBPs) following abiotic stresses in Arabidopsis thaliana. In transgenic Arabidopsis Class II AtACBP1overexpressors (OEs), PLD 1 was induced upon cold stress, causing a decrease in the ratio of PC to PA leading to membrane instability and freezing sensitivity [88]. In contrast, transgenic Arabidopsis Class I AtACBP6-OEs were conferred freezing tolerance via the PLD -mediated pathway in rosettes and the ABA-mediated pathway in flowers, resulting in changes in lipids, sugars and stress-related genes [87,123]. During drought, transgenic Arabidopsis Class II AtACBP2-OEs exhibited elevated AtAREB1 and AtRBOHF expression which led to ROS production, subsequent stomatal closure and reduced water loss [90]. Proper stem cuticle development conferred by Class I AtACBP6, Class III AtACBP3 or Class IV AtACBP4 protects wild-type Arabidopsis from water loss [25]. Under high salinity, AtACBP1 and AtAREB1 expression were upregulated in wild-type seeds [80]. The overexpression of AtACBP1 in transgenic Arabidopsis triggers nuclear translocation of AtAREB1, leading to the induction of stress marker genes (RD22 and RD29B) and AtAREB1 target genes (PKS5 and RAB18), thereby promoting stronger ABA responses during seed germination and seedling establishment [80]. When wild-type Arabidopsis undergoes hypoxia, the RAP2.12 transcription factor bound to AtACBP1 or AtACBP2, translocates to the nucleus and activates hypoxia-responsive gene transcription, conferring hypoxic protection [77,128,134,139]. Another hypoxic tolerance pathway involves the interaction of unsaturated VLC ceramide and the CTR1 protein with subsequent nuclear translocation of EIN2, resulting in the activation of CTR1-mediated ethylene signalling [137]. AtACBP1 is involved in phytoremediation and its overexpression in transgenic Arabidopsis confers Pb(II) tolerance [135]. AtACBP2 can interact with AtFP6 or LYSOPL2, mediating heavy metal transport and phospholipid repair respectively, and hence transgenic Arabidopsis AtACBP2-OEs were resistant to Cd(II) and Cd(II)-induced oxidative stress [75,76,82]. On wounding, the up-regulation of $A t A C B P 3$ and AtACBP6 expression in the wild type suggested their involvement in JA-mediated local and systemic wound responses [125,126]. Orange and yellow boxes indicate transgenic Arabidopsis AtACBP-OEs and wild-type Arabidopsis AtACBPs respectively, used in studies on abiotic stress. Blue boxes represent the signalling pathways. White boxes indicate the molecular events that occur along the signalling pathway. Red and blue arrows indicate increase and a decrease, respectively. Black arrows denote the flow of events. ABA, abscisic acid; ACBP, acyl-CoA-binding protein; AREB1, ABA-RESPONSIVE ELEMENT BINDING PROTEIN1; FP6, FARNESYLATED PROTEIN6; COR, COLD-RESPONSIVE; CTR1, CONSTITUTIVE TRIPLE RESPONSE1; EIN2, ETHYLENE-INSENSITIVE2; JA, jasmonic acid; LYSOPL2, LYSOPHOSPHOLIPASE2; MGDG, monogalactosyldiacylglycerol; PA, phosphatidic acid; PC, phosphatidylcholine; PKS5, PROTEIN KINASE SOS2-LIKE5; PLD, PHOSPHOLIPASE D; RAB18, RESPONSIVE TO ABA18; RAP2.12, RELATED TO APETALA2.12; RBOHF, RESPIRATORY BURST OXIDASE HOMOLOG F; RD, RESPONSIVE TO DESSICATION; ROS, reactive oxygen species; VLC, very-long-chain. 


\subsection{Drought Stress}

Drought stress has received massive attention as it threatens worldwide crop production. ABA is a plant hormone that plays vital roles in many physiological processes including responses to abiotic stresses such as drought and salinity [140]. Under water deficiency, plants produce adaptive responses through the expression of various genes upon elevation of ABA [141,142]. Many signal transducers have been reported to participate in ABA signalling, including PA, diacylglycerol (DAG), phosphoinositides, reactive oxygen species (ROS), cyclic adenosine 5'-diphosphate ribose, sphingosine 1-phosphate and calcium [143-152].

Class II membrane-associated AtACBP2 responds to drought stress via ABA signalling (Figure 1) [90]. AtACBP2 expression was induced by ABA and drought treatment in wildtype Arabidopsis seedlings [90]. On top of that, transgenic Arabidopsis AtACBP2-OEs showed better drought tolerance than the wild type, whereas the atacbp 2 mutant plants were more sensitive after drought treatment [90]. ABA-signalling genes including AREB1 and RESPIRATORY BURST OXIDASE HOMOLOG F (AtRBOHF) were upregulated in AtACBP2-OE before and after ABA treatment while AtRBOHD and ABA DEFICIENT2 $(A B A 2)$ increased only after ABA treatment. These results support the role of AtACBP2 in ABA signalling and hence in drought tolerance, as characterized by stomatal closure and reduced water loss [90].

It has been suggested that AtACBP3, AtACBP4 and AtACBP6 can regulate drought tolerance through stem cuticle formation (Figure 1) [25]. Transmission electron microscopy (TEM) showed that the leaves of the atacbp3, atacbp 4 and atacbp 6 mutants each had an abnormal and more permeable cuticle in comparison to the wild type, resulting in water loss after drought stress [25]. Furthermore, marked changes of cuticular wax and cutin monomer profiles in atacbp3, atacbp 4 and atacbp 6 single mutant plants depicted that AtACBPs play an important role in cuticle formation as well as in drought tolerance [25]. In soybean, expression profiles of roots were analysed by RNA-seq following dehydration stress [153]. Data mining of GmACBP expression by Azlan et al. [104] revealed that Class II (GmACBP3 and GmACBP4), Class III (GmACBP7) as well as Class IV (GmACBP9) were induced, suggesting that these GmACBPs play a role in drought response.

\subsection{Salinity Stress}

High salt in soil is detrimental to plant growth and development, and this in turn severely affects the crop yield worldwide. Salt stress can induce other stresses including osmotic stress, ionic stress and oxidative stress [154,155]. Osmotic stress arises from the reduction of water potential due to high amount of salt at the root surface, leading to a reduction in water uptake by the plant [156]. Ionic stress occurs as there is excessive uptake of sodium $\left(\mathrm{Na}^{+}\right)$and chloride $\left(\mathrm{Cl}^{+}\right)$ions by plant roots, which eventually accumulate in leaves [157]. Besides, ROS production also increases upon exposure to salt stress, causing oxidative stress in plants [158-163].

Salt sensing and signalling are complex. One of the early salt-signalling components are phospholipids, including polyphosphoinositides and PA [164,165]. PI signalling triggers the biosynthesis of phosphoinositides and JA-related proteins upon salt stress and can rapidly remodel soybean lipid composition for stress adaption [166]. Under salt stress, $\mathrm{Na}^{+}$homeostasis is regulated by the SALT OVERLY SENSITIVE (SOS) pathway whereby $\mathrm{Na}^{+}$influx promotes PLD $\alpha 1$ enzyme activity, causing a rise in PA levels [167]. Acting as a signal relay, PA activates MITOGEN-ACTIVATED PROTEIN KINASE6 (MPK6) which then phosphorylates SOS1, a potential intracellular $\mathrm{Na}^{+}$sensor [168-170]. Several pld mutants exhibit enhanced sensitivity to salt stress [171].

ChACBP1, isolated from the algae (Chlorella sp.) JB6, was induced under various abiotic stresses including salinity, oxidation, heavy metals and cold stresses [92]. Given the binding of rChACBP1 protein to PC and the improved tolerance of yeast and Arabidopsis overexpressing ChACBP1 to abiotic stresses, these responses may be mediated through phospholipid metabolism [92]. Following $\mathrm{NaCl}$ or mannitol treatment of Arabidopsis 
seeds, the expression of $A t A C B P 1$ and its protein partner AtAREB1 were upregulated over the water-treated control [80]. The overexpression of AtACBP1 rendered higher sensitivity of transgenic Arabidopsis to $\mathrm{NaCl}$ or mannitol treatment during seed germination and seedling establishment over the wild type, whereas the atacbp 1 mutant was less sensitive during seed germination but not seedling establishment (Figure 1) [80]. In transgenic Arabidopsis DsRed-AtAREB1/AtACBP1-OEs, the overexpression of AtACBP1 led to nuclear translocation of DsRed-AtAREB1 [80]. Salt and osmotic stress marker genes (RD22 and $R D 29 B$ ) and AtAREB1 target genes (PKS5 and RAB18) were also induced in AtACBP1OEs [80]. These results suggested that enhanced AtAREB1 production in AtACBP1-OEs promotes stronger ABA responses during seed to seedling transition when AtAREB1 is released from AtACBP1 to enter the nucleus (Figure 1) [80]. A recent study revealed that the overexpression of OsACBP4 and AtACBP2 conferred salt resistance in both transgenic rice and Arabidopsis [94]. Four salinity-responsive elements in the OsACBP4 5'-flanking region were confirmed to interact with nuclear proteins from salt-treated rice [94]. On top of that, the up-regulation of genes encoding acyl-CoA synthase under salt stress and the binding of rOsACBP4 to long-chain acyl-CoA esters suggested that OsACBP4 may regulate salinity responses via lipid metabolism [94].

A recent study by Zhu et al. [103] showed that Class I ZmACBP1 and Class II ZmACBP3 gene expression was induced after $\mathrm{NaCl}$ or mannitol treatment. Transgenic Arabidopsis overexpressing $\mathrm{ZmACBP} 1$ and $\mathrm{ZmACBP3}$ exhibited better growth and longer roots in comparison to the vector control [103]. The expression levels of the lipid metabolic genes (FAD2, $D G A T, P L A 2, P L C 3$, and $A C X)$ and stress-responsive genes (COR47, AREB1, RAB, ABI1, $R D 29 A$, and $R D 29 B$ ) under $\mathrm{NaCl}$ or mannitol significantly increased in ZmACBP3-OEs compared to the wild type [103]. These results suggested that $Z m A C B P 3$ overexpression may enhance stress tolerance through changes in lipid metabolism which led to the induction of stress-responsive genes [103]. In soybean response to $\mathrm{NaCl}$ stress, in silico analysis of GmACBP expression from RNA-seq data exhibited induction of Class II GmACBP3, Class III GmACBP7 and Class IV GmACBP9, but decreases in Class I GmACBP2 and Class IV GmACBP10 [104]. As only Arabidopsis and rice Class II ACBPs have been reported in the $\mathrm{NaCl}$ response, the greater increase of Class III GmACBP7 than Class II GmACBP3 expression implied different roles for GmACBPs in soybean [104].

\subsection{Hypoxic Stress}

Plants need oxygen for respiration. Hypoxia happens when plants encounter oxygen deprivation, usually arising from flooding and soil waterlogging. Plants regulate their oxygen-sensing ability by transcription factors belonging to group VII of the ETHYLENERESPONSE FACTORS (ERF-VIIs) which are protected against proteasomal degradation only under hypoxia [77]. The stabilized ERF-VIIs can translocate to the nucleus and bind the HYPOXIA-RESPONSIVE PROMOTOR ELEMENT (HRPE) to drive the transcription of anaerobic genes [172]. ERF-VII transcription factor, AtEBP interacts with AtACBP2 via the ankyrin repeats although AtEBP is colocalised to the nucleus, whereas AtACBP2 is found on the plasma membrane [73]. Under aerobic conditions, RAP2.12 interacts with AtACBP1 and AtACBP2 at the plasma membrane, preventing its translocation to the nucleus and protecting it from $\mathrm{N}$-end rule degradation [77]. When hypoxia arises, RAP2.12 is transported to the nucleus to activate the transcription of hypoxia-responsive genes (Figure 1) [139]. Polyunsaturated 18:3-CoA was proven to regulate the release of RAP2.12 from the plasma membrane upon hypoxia [128]. Upon submergence, wild-type Arabidopsis significantly accumulated polyunsaturated 18:3-CoA [128]. Confocal microscopy and immunoblot analysis showed that 18:3-CoA promoted stronger stabilization of RAP2.12-GFP, HYPOXIA RESPONSIVE ERF 1 (HRE1)-GFP and RAP2.3-GFP fusions [128]. In vitro pull-down assays revealed that both 18:0- and 18:3-CoAs suppress the interaction of AtACBP1 and ERF-VII, suggesting that 18:3-CoA can modulate the dissociation of the AtACBP1-ERF-VII complex when hypoxia arises [128]. Moreover, 18:3-CoA treatment of atacbp1 AtACBP2-RNAi lines indicates that AtACBP1 and AtACBP2 are important for the 18:3-CoA-induced stabiliza- 
tion of RAP2.12 and induction of hypoxia-responsive genes [128]. In addition, cellular energy depletion following hypoxia increased 18:1-CoA levels, triggering the dissociation of AtACBP1-bound RAP2.12 and its subsequent nuclear translocation for the activation of hypoxic gene transcription [134].

Other than Class II AtACBPs, AtACBP3 also plays a role in hypoxic response in Arabidopsis through binding of VLC acyl-CoA esters and regulation of fatty acid metabolism such as unsaturated VLC ceramides [136]. The interaction of unsaturated VLC ceramide with the CONSTITUTIVE TRIPLE RESPONSE1 (CTR1) protein promoted nuclear translocation of ETHYLENE-INSENSITIVE2 (EIN2), triggering CTR1-mediated ethylene signalling for hypoxic protection in Arabidopsis (Figure 1) [137]. Besides ceramides and acyl-CoAs, other lipids including phospholipids, galactolipids, oxylipins, wax and cutin are important in plant hypoxic responses [173]. Upon submergence, total PC, PE and phosphatidylglycerol (PG) content declined but phosphatidylserine (PS), PA, PI, oxidized lipid, ceramide and hydroxyceramide levels increased significantly [136,137]. Moreover, significant increase of oxidized galactolipids [MGDG and digalactosyldiacylglycerol (DGDG)] and phospholipids (PC, PE and PG), arabidopsides and malondialdehyde (MDA), implied that an oxidative burst occurs during hypoxia or posthypoxic reoxygenation, leading to significant lipid peroxidation $[128,137,174]$. In addition, transcriptomic analyses have shown changes in the expression of genes encoding proteins essential for the ceramide and sphingolipid LCB biosynthesis [137], lipid transfer, and wax and cutin transport during submergence [27]. Moreover, JA biosynthesis genes were enhanced upon postsubmergence reoxygenation, implicating that oxylipins may modulate the posthypoxic reoxygenation response in plants [174].

\subsection{Heavy Metal and Oxidative Stresses}

Heavy metals such as lead [Pb(II)], cadmium [Cd(II)] and zinc [ $\mathrm{Zn}(\mathrm{II})]$ are major pollutants threatening the environment and living organisms. Therefore, several studies have been performed to investigate the role of AtACBPs in response to heavy metal stresses $[75,135]$. Using metal-chelate affinity chromatography and fluorescence analysis using dansyl aziridine-labelled proteins, rAtACBP1 was reported to bind $\mathrm{Pb}(\mathrm{II})$ [135]. The overexpression of AtACBP1 in transgenic Arabidopsis showed better tolerance to $\mathrm{Pb}(\mathrm{II})$ stress, whereas the atacbp1 mutant was more sensitive to $\mathrm{Pb}$ (II) (Figure 1). Accumulation of $\mathrm{Pb}(\mathrm{II})$ in the shoots of $A t A C B P 1$-overexpressing plants suggested a possible role of AtACBP1 in $\mathrm{Pb}$ (II) phytoremediation [135]. Besides AtACBP1, the expression of AtACBP4 was also induced by $\mathrm{Pb}(\mathrm{II})$ in both Arabidopsis shoots and roots [124]. When transgenic Brassica juncea expressing AtACBP1 and AtACBP4 were grown in $\mathrm{Pb}$ (II)-containing media, $\mathrm{Pb}$ (II) accumulated in the cytosol of root tips and the vascular tissues, further corroborating to the function of AtACBPs in phytoremediation [124].

AtACBP2, on the other hand, is responsive to $\mathrm{Cd}(\mathrm{II})$. Although there was no accumulation of heavy metals in AtACBP2-overexpressing plants, the overexpression of AtACBP2 enhanced tolerance to $\mathrm{Cd}(\mathrm{II})$ and oxidative stress (hydrogen peroxide, $\mathrm{H}_{2} \mathrm{O}_{2}$ ) in transgenic Arabidopsis (Figure 1) [75]. In the plasma membrane, AtACBP2 interacts via its ankyrin repeats with AtFP6, which has a metal-binding motif [75]. In Arabidopsis roots, AtFP6 expression was induced after Cd(II) treatment [75]. The overexpression of AtFP6 conferred better $\mathrm{Cd}(\mathrm{II})$ resistance than the wild type, possibly by mediating heavy metal transport in plants [75]. LYSOPL2, another protein interactor of AtACBP2, is an intermediate of phospholipid metabolism and detoxifies lysoPC [76]. LYSOPL2 expression was induced by $\mathrm{Zn}(\mathrm{II})$ and $\mathrm{H}_{2} \mathrm{O}_{2}$ in Arabidopsis. The overexpression of LYSOPL2 in Arabidopsis exhibited enhanced tolerance to $\mathrm{Cd}$ (II) and $\mathrm{H}_{2} \mathrm{O}_{2}$ in comparison to the wild type, suggesting the involvement of LYSOPL2 in phospholipid repair following metal-induced lipid peroxidation (Figure 1) [76]. Possibly, the efficiency of membrane repair could be improved by the formation of an AtLYSOPL2-AtACBP2 complex, facilitated by lysoPC binding to AtACBP2 [82]. 


\subsection{Wounding}

In plants, wounding results following biotic attack (herbivores, insects and pathogens), mechanical damage or weather-induced damage, which may culminate in the entry of pathogens and nutrient loss. Mechanical injury triggers the transduction of mobile signals in the plants, leading to localised responses at the wound sites (local response) and distal responses in the undamaged tissues (systemic response) [175]. Cell wall-derived oligogalacturonides (OGs) and a polypeptide systemin are well-characterized wounding signals [176]. Upon wounding, systemin interacts with a cell-surface receptor to trigger several signalling events, including the release of linolenic acid from plant cell membranes and its conversion to 12 oxo-phytodienoic acid (OPDA) and JA [175,177,178]. The accumulation of JA in wounded plants subsequently activates various defence genes encoding proteinase inhibitor, thionin and enzymes involved in secondary metabolism [179].

Both Class I AtACBP6 and Class III AtACBP3 are involved in the local and systemic wound responses in Arabidopsis [125,126]. AtACBP6 and AtACBP3 proteins are localised to the companion cells, sieve elements and phloem $[125,126]$. On wounding, AtACBP6 and AtACBP3 were induced in Arabidopsis [125,126]. In comparison to atacbp3 and AtACBP3RNAi plants, wound-responsive JA marker genes such as JASMONATE ZIM-DOMAIN10, VEGETATIVE STORAGE PROTEIN2 and LIPOXYGENASE2, were upregulated more significantly in locally wounded and systemic wild-type leaves [126]. Besides, lower levels of MeJA and oxylipin-related FAs, including C18:2-FA and C18:3-FA, were observed in atacbp3 and AtACBP3-RNAi over wild-type phloem exudates [126]. ITC data showed that rAtACBP3 binds medium and long-chain acyl-CoA esters but not MeJA, suggesting that AtACBP3 maintains FA pool but does not transport MeJA in the phloem [126]. Taken together, the evidence indicated that AtACBP3, a phloem-mobile protein, possibly regulates JA-mediated local and systemic wound responses by its binding to acyl-CoA esters (Figure 1). Besides $A t A C B P 3$ and $A t A C B P 6$, rice $O s A C B P 5$ and $O s A C B P 6$, as well as several maize $\mathrm{Z} m A C B P s$ ( $\mathrm{Z} m A C B P 1, \mathrm{Z} m A C B P 2, \mathrm{Z} m A C B P 5$ and $\mathrm{Z} m A C B P 6)$, were rapidly induced after wound treatment $[89,103]$. However, their specific roles in wound response remain to be elucidated.

\section{Membrane Lipids and ACBPs in Pathogen Defense}

Under the natural environment, plants are always exposed to a variety of bacterial and fungal pathogens. Several AtACBPs, such as AtACBP1, AtACBP3, AtACBP4 and AtACBP6, and Class III OsACBP5, have been reported to participate in plant defence against infections caused by bacterial and fungal pathogens (Figure 2) $[25,26,93,121,127]$. AtACBP3 expression was induced in wild-type Arabidopsis following pathogen infection (Pseudomonas syringae pv tomato DC3000 and Botrytis cinerea) and treatments using pathogen elicitors (arachidonic acid) and defence-related phytohormones [1-aminocyclopropane-1-carboxylic acid (ACC), MeJA and salicylic acid (SA)] [121]. An S-box (TTTAA) regulatory element identified at the AtACBP3 5'-flanking region was verified by electrophoretic mobility shift assay (EMSA) to bind nuclear proteins from pathogen-infected Arabidopsis leaves [122]. In addition, overexpression of AtACBP3 led to constitutive activation of pathogenesis-related (PR) genes, including PR1, PR2 and $P R 5, \mathrm{H}_{2} \mathrm{O}_{2}$ production and cell death (Figure 2) [121]. Following P. syringae pv tomato DC3000 infection, a lower bacterial count signified better protection of AtACBP3-OEs against the pathogen in comparison to the wild type and atacbp3 mutant [121]. To determine whether the upregulation of $P R$ genes is associated with the NONEXPRESSOR OF PR-1 (NPR1) or CORONATINE-INSENSITIVE1 (COI1) signalling pathway, transgenic Arabidopsis of the AtACBP3-OEnpr1 line was subject to $P$. syringae treatment [121]. Results showed that the $P R$ genes were downregulated in AtACBP3-OEnpr1 and they no longer exhibit enhanced resistance to P. syringae infection, implying that the pathogen protection of AtACBP3-OEs is mediated by the NPR1 signalling pathway [121]. As AtACBP3-OEs were more susceptible to necrotrophic fungus B. cinerea infection compared to atacbp3, AtACBP3 is believed to play a differential role in the plant defence response against necrotrophic and biotrophic pathogens [121]. Apart from abiotic 
stress, grape VvACBP which belongs to the same Class III as AtACBP3, also plays a role in pathogen defence (Figure 2) [100]. The expression of VvACBP in transgenic Arabidopsis conferred resistance to P. syringae pv tomato DC3000 and Colletotrichum higginsianum upon infection [100].
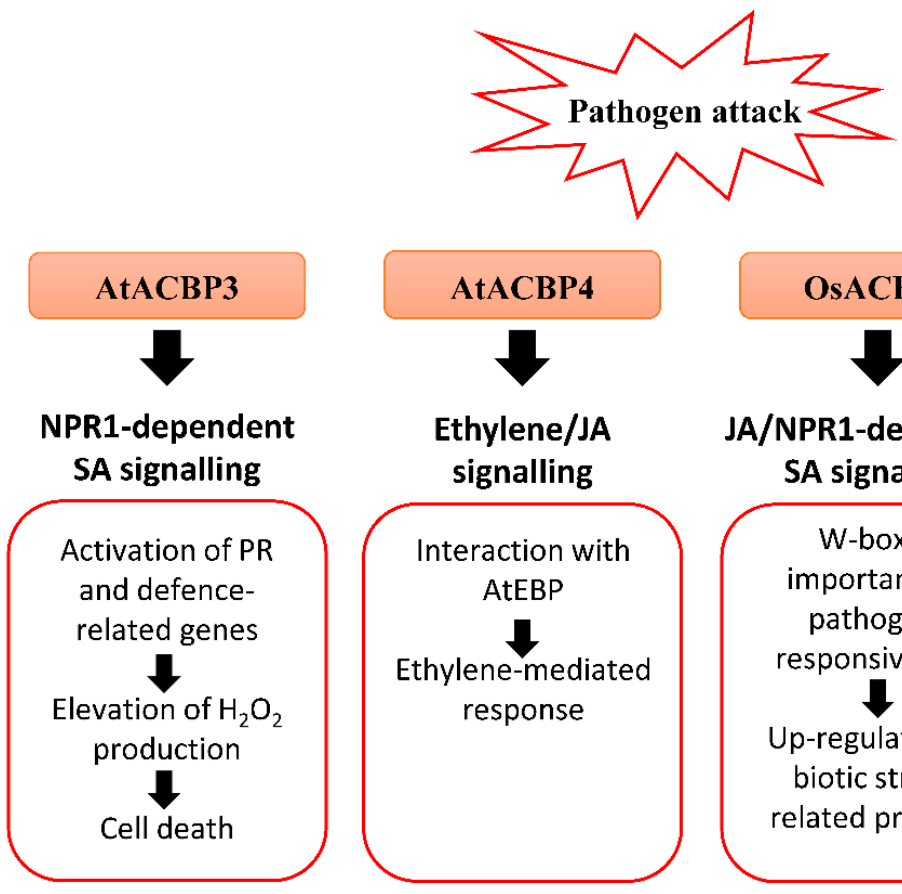

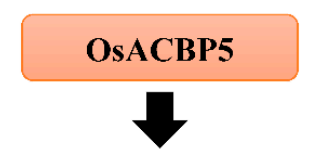

JA/NPR1-dependent SA signalling

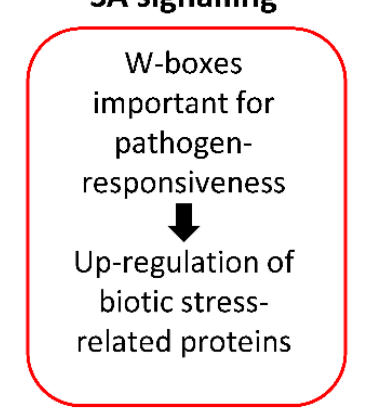

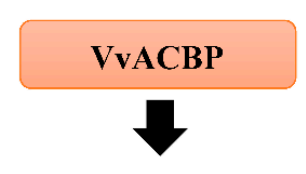

NPR1-dependent signalling

Induction of plant defensin PDF1.2

$\downarrow$

Acquisition of disease resistance

Figure 2. Biotic stress-related signalling pathways associated with acyl-CoA-binding proteins (ACBPs) in plants. Upon pathogen infection, the overexpression of Class III AtACBP3 in transgenic Arabidopsis thaliana led to constitutive activation of pathogenesis-related (PR) genes including $P R 1, P R 2$ and $P R 5$, elevated $\mathrm{H}_{2} \mathrm{O}_{2}$ production and eventually cell death [121]. AtACBP3 plays a distinct role in the plant defence response against necrotrophic and biotrophic pathogens as transgenic Arabidopsis AtACBP3-overexpressors (OEs) were protected against the biotrophic pathogen (Pseudomonas syringae pv tomato DC3000) but not the necrotrophic pathogen (Botrytis cinerea) [121]. In wild-type Arabidopsis, the expression of Class IV AtACBP4 and AtEBP encoding a protein interactor of AtACBP4 were reported to be induced by B. cinerea infection, and ethylene precursor 1-aminocyclopropane-1-carboxylic acid (ACC) and methyl jasmonate (MeJA) treatments, suggesting that AtACBP4 and AtEBP are mediated by ethylene and/or JA signalling [74]. Rice Class III OsACBP5 protects transgenic Arabidopsis and rice plants against hemibiotrophs and biotrophs via NPR1-dependent SA signalling, and necrotrophs by JA signalling $[93,127]$. The OsACBP5 5'-flanking region contains W-boxes which were verified in pathogen-responsiveness of OsACBP5 [93]. Proteomic studies showed that eleven biotic stress-related proteins were upregulated by Rhizoctonia solani infection in transgenic Arabidopsis OsACBP5-OEs [127]. Grape Class III VvACBP conferred resistance to P. syringae and Colletotrichum higginsianum in transgenic Arabidopsis, possibly through the NPR1-mediated pathway following induction of PDF1.2, the gene encoding plant defensin [100]. Orange boxes represent the named ACBPs involved in the pathogen response. White boxes indicate the molecular events that occur along the signalling pathway. Black arrows denote the flow of signalling events. ACBP, acyl-CoA-binding protein; EBP, ETHYLENE-RESPONSIVE BINDING PROTEIN; JA, jasmonic acid; NPR1, NONEXPRESSOR OF PR-1; PR, pathogenesis-related; SA, salicylic acid.

The expression of Class IV AtACBP4 and its protein interactor $A t E B P$ were elevated following $B$. cinerea infection, as well as the ethylene precursor ACC and MeJA treatments (Figure 2) [74]. The interaction of AtACBP4 and AtEBP, as confirmed by yeast two-hybrid and coimmunoprecipitation, suggests that plant pathogen defence may be mediated by ethylene and/or JA signalling [74]. Another study revealed that atacbp3, atacbp4 and atacbp 6 single mutants exhibited a defective cuticle that resulted in compromised systemic acquired resistance (SAR) to fungal (B. cinerea and C. higginsianum) and bacterial (P. syringae) pathogens [25]. Furthermore, AtACBP1 which is also important for stem cuticle formation, is suggested to confer resistance to B. cinerea [26]. 
Apart from AtACBPs, recent studies have depicted that Class III OsACBP5, the homologue of AtACBP3, protects rice plants against representative necrotrophic (Rhizoctonia solani and Cercospora oryzae), hemibiotrophic (Magnaporthe oryzae and Fusarium graminearum) and biotrophic (Xanthomonas oryzae) phytopathogens (Figure 2) [93]. Transgenic rice OsACBP5-OEs demonstrated stronger disease resistance against all pathogens tested [93]. In addition, enhanced resistance of OsACBP5-OEs against hemibiotrophs and biotrophs is mediated by SA signalling, while that against the necrotrophic pathogen $R$. solani is regulated by JA signalling [93]. In the OsACBP5 5'-flanking region of the four W-boxes (pathogen-responsive cis-elements) identified, EMSAs showed that two of them bound nuclear proteins from wild-type rice infected with $R$. solani, C. oryzae, M. oryzae and X. oryzae [93]. Furthermore, transgenic rice expressing the construct of the OsACBP5 5'flanking region containing both these $\mathrm{W}$-boxes fused to the gene encoding $\beta$-glucuronidase (GUS) exhibited higher GUS activity upon SA, MeJA or R. solani treatment compared to the promoter deletion lacking both W-boxes [93]. These results suggest that the $\mathrm{W}$-boxes are important in the pathogen-responsiveness of OSACBP5.

Both Lipidex assays and ITC showed that rOsACBP5 binds to 18:3-CoA esters, suggesting that 18:3-FA, a precursor for JA biosynthesis, plays a role in basal defence against fungal pathogens $[89,93]$. Furthermore, proteomic analysis revealed that eleven biotic stress-related proteins were upregulated by $R$. solani infection in transgenic Arabidopsis OsACBP5-OEs. These proteins include cell wall-related proteins such as FASCILIN-LIKE ARABINOGALACTAN-PROTEIN10 (FLA10), LEUCINE-RICH REPEAT EXTENSIN-LIKE PROTEINS (LRX4 and LRX5), XYLOGLUCAN ENDOTRANSGLUCOSYLASE/HYDROLASE PROTEIN4 (XTH4) and PECTINESTERASE INHIBITOR18 (PME18), proteins involved in glucosinolate (GSL) degradation including GDSL-LIKE LIPASE23 (GLL23), EPITHIOSPECIFIER MODIFIER1 (ESM1), MYROSINASE1, MYROSINASE2, NITRILASE1 (NIT1), and a protein involved in JA synthesis, ALLENE OXIDE CYCLASE2 (AOC2), suggesting their potential in protection against $R$. solani [127].

Upon Phakopsora pachyrhizi fungal infection of soybean, seven GmACBPs comprising all four classes were detected in microarray data analysis [104]. The expression of Class I GmACBP2, Class II GmACBP4, Class III GmACBP5 and GmACBP6, and Class IV GmACBP11 declined after $6 \mathrm{~h}$ post inoculation (hpi) of soybean with avirulent Hawaii 94-1 and virulent Taiwan 80-2 strains [104]. In addition, Phytophthora sojae infection caused an induction of only Class IV GmACBP9 at $72 \mathrm{hpi}$, but a reduction of other GmACBPs such as Class I GmACBP2, Class III GmACBP5, GmACBP6 and GmACBP7 as well as Class IV GmACBP11 after 48 dpi [104]. Such differential changes in GmACBPs compared to other Class III ACBPs such as $A t A C B P 3, V v A C B P$ and $O s A C B P 5$ in pathogen response, suggested differential roles of GmACBPs in plant-pathogen interactions.

\section{Conclusions and Perspectives}

Studies on ACBPs in the past two decades have strongly implicated their roles in the regulatory mechanisms of development and stress responses. All classes of ACBPs are known to play a role in abiotic and biotic stress signalling, although the detailed mechanistic events remain to be further elucidated. Through phospholipid and acyl-CoA ester binding, AtACBPs and OsACBPs are involved in stresses arising from drought [22,81], adverse temperatures [87,88,123], salinity [80], oxidation [76], hypoxia [73,77,128,136,137], heavy metals $[75,76,120,124]$, wounding $[125,126]$ and pathogens $[74,93,100,121,122,127]$. Moreover, the identification of ACBP protein interactors including AREB1 [80], RAP2.12 [77,128,134], AtEBP [73,74], AtFP6 [75], and LYSOPL2 [76,82], also lead to a better understanding of the signalling pathways of stress responses.

Taken together, dicot AtACBPs have been widely studied in relation to their acyl$\mathrm{CoA}$ and phospholipid binding properties, protein-protein interaction and the resultant signalling cascades of abiotic and biotic stress responses. However, the roles of the monocot OsACBPs and ZmACBPs, as well as the emerging leguminous GmACBPs, remain to be further investigated given that preliminary studies have shown stress-induced changes in ACBP expression $[89,103,104]$. Thus far, only Class II OsACBP4 and Class III OsACBP5 
have been proven to confer salinity and pathogen resistance, respectively, in transgenic Arabidopsis and rice $[93,94,127]$. As various stress treatments induced the expression of OsACBPs [89], it would be interesting to identify their protein partners involved in these stress responses. In comparison to Arabidopsis, differential GmACBP expression in soybean upon salt and drought treatment suggests that soybean stress responses may differ from Arabidopsis [104], opening a new path to expand the study of leguminous GmACBPs in stress regulation. In view of the rapid growth in the global population, the discovery and knowledge of AtACBP-conferred stress resistance may be applicable in tackling food security issues related to crop protection in rice [89,93,94] and maize [103], and the production of engineered oil crops in sunflower [101,118] and oil palm [102]. The overexpression of ACBPs in developing seeds presents a molecular tool for the modification of nutritional and oil content in oil crops [85,130,131,180].

It is known that ACBPs play significant roles in plant development and stress responses $[25,26,74,76,78,80,81,87,88,93,112,116,117,119,132]$, but the interplay between development and stress regulation is not well elucidated. For example, the overexpression of AtACBP1 not only plays a role in salt stress regulation [80], but also regulates seed dormancy and germination as well as seedling development through ABA signalling $[78,80]$. Nonetheless, their direct relationship is still not known, as complex signalling events of crosstalk between proteins, hormones and metabolites may be involved [181-183]. However, the use of lipidomics, proteomics, transcriptomics and other new technologies is expected to help unravel these comprehensive mechanisms to better understand their interactions.

Author Contributions: Conceptualization, S.-H.L. and M.-L.C.; writing-original draft preparation, S.-H.L. and M.-L.C.; visualization, S.-H.L. and M.-L.C.; writing-review and editing, S.-H.L. and M.-L.C. All authors have read and agreed to the published version of the manuscript.

Funding: This research was funded by the Wilson and Amelia Wong Endowment Fund, Hong Kong Research Grants Council Area of Excellence Schemes (AoE/M-403/16 and AoE/M-05/12), the General Research Fund (17101818 and 17109917), and the Innovation Technology Fund of the Innovation Technology Commission (Funding Support to the State Key Laboratory of Agrobiotechnology in Hong Kong).

Institutional Review Board Statement: Not applicable.

Informed Consent Statement: Not applicable.

Data Availability Statement: Not applicable.

Acknowledgments: We thank Shiu-Cheung Lung and Ze-Hua Guo for critically reviewing the manuscript.

Conflicts of Interest: The authors have no conflict of interest to declare.

\section{References}

1. Pritchard, S.L.; Charlton, W.L.; Baker, A.; Graham, I.A. Germination and storage reserve mobilization are regulated independently in Arabidopsis. Plant J. 2002, 31, 639-647. [CrossRef]

2. Wallis, J.G.; Browse, J. Mutants of Arabidopsis reveal many roles of membrane lipids. Prog. Lipid Res. 2002, 41, 254-278. [CrossRef]

3. Casares, D.; Escribá, P.V.; Rosselló, C.A. Membrane lipid composition: effect on membrane and organelle structure, function and compartmentalization and therapeutic avenues. Int. J. Mol. Sci. 2019, 20, 2167. [CrossRef]

4. Huang, A.H.C. Oil bodies and oleosins in seeds. Annu. Rev. Plant Physiol. Plant Mol. Biol. 1992, 43, 177-200. [CrossRef]

5. Takahashi, K.; Morimoto, R.; Tabeta, H.; Asaoka, M.; Ishida, M.; Maeshima, M.; Tsukaya, H.; Ferjani, A. Compensated cell enlargement in fugu 5 is specifically triggered by lowered sucrose production from seed-storage lipids. Plant Cell Physiol. 2017, 58, 668-678. [CrossRef]

6. Fan, J.; Zhou, C.; Yu, L.; Li, P.; Shanklin, J.; Xu, C. Diversion of carbon flux from sugars to lipids improves the growth of an Arabidopsis starchless mutant. Plants 2019, 8, 229. [CrossRef]

7. Harwood, J.L. Recent advances in the biosynthesis of plant fatty acids. Biochim. Biophys. Acta. 1996, 31, 7-56. [CrossRef]

8. Ohashi, Y.; Oka, A.; Rodrigues-Pousada, R.; Possenti, M.; Ruberti, I.; Morelli, G.; Aoyama, T. Modulation of phospholipid signaling by GLABRA2 in root-hair pattern formation. Science 2003, 300, 1427-1430. [CrossRef] 
9. Fujii, S.; Kobayashi, K.; Nakamura, Y.; Wada, H. Inducible knockdown of MONOGALACTOSYLDIACYLGLYCEROL SYNTHASE1 reveals roles of galactolipids in organelle differentiation in Arabidopsis cotyledons. Plant Physiol. 2014, 166, 1436-1449. [CrossRef] [PubMed]

10. Lin, Y.T.; Chen, L.J.; Herrfurth, C.; Feussner, I.; Li, H.S. Reduced biosynthesis of digalactosyldiacylglycerol, a major chloroplast membrane lipid, leads to oxylipin overproduction and phloem cap lignification in Arabidopsis. Plant Cell 2016, 28 , $219-232$. [CrossRef]

11. Laxalt, A.M.; Riet, B.T.; Verdonk, J.C.; Parigi, L.; Tameling, W.I.L.; Vossen, J.; Haring, M.; Musgrave, A.; Munnik, T. Characterization of five tomato phospholipase D cDNAs: rapid and specific expression of LePLD $\beta 1$ on elicitation with xylanase. Plant J. 2001, 26, 237-247. [CrossRef] [PubMed]

12. Munnik, T. Phosphatidic acid: An emerging plant lipid second messenger. Trends Plant Sci. 2001, 6, 227-233. [CrossRef]

13. Weber, H. Fatty acid-derived signals in plants. Trends Plant Sci. 2002, 7, 217-224. [CrossRef]

14. Meijer, H.J.G.; Munnik, T. Phospholipid-based signaling in plants. Annu. Rev. Plant Biol. 2003, 54, 265-306. [CrossRef] [PubMed]

15. Xiao, S.; Chye, M.L. New roles for acyl-CoA-binding proteins (ACBPs) in plant development, stress responses and lipid metabolism. Prog. Lipid Res. 2011, 50, 141-151. [CrossRef] [PubMed]

16. Vu, H.S.; Roston, R.; Shiva, S.; Hur, M.; Wurtele, E.S.; Wang, X.; Shah, J.; Welti, R. Modifications of membrane lipids in response to wounding of Arabidopsis thaliana leaves. Plant Signal. Behav. 2015, 10, e1056422. [CrossRef]

17. Wang, P.; Shen, L.; Guo, J.; Jing, W.; Qu, Y.; Li, W.; Bi, R.; Xuan, W.; Zhang, Q.; Zhang, W. Phosphatidic acid directly regulates PINOID-dependent phosphorylation and activation of the PIN-FORMED2 auxin efflux transporter in response to salt stress. Plant Cell 2019, 31, 250-271. [CrossRef]

18. Qin, L.; Zhou, Z.; Li, Q.; Zhai, C.; Liu, L.; Quilichini, T.D.; Gao, P.; Kessler, S.A.; Jaillais, Y.; Datla, R.; et al. Specific recruitment of phosphoinositide species to the plant-pathogen interfacial membrane underlies Arabidopsis susceptibility to fungal infection. Plant Cell 2020, 32, 1665-1688. [CrossRef]

19. Christie, W.W.; Harwood, J.L. Oxidation of polyunsaturated fatty acids to produce lipid mediators. Essays Biochem. 2020, 64, 401-421. [CrossRef]

20. Griffiths, G. Jasmonates: biosynthesis, perception and signal transduction. Essays Biochem. 2020, 64, 501-512. [CrossRef]

21. Kim, S.C.; Wang, X. Phosphatidic acid: an emerging versatile class of cellular mediators. Essays Biochem. 2020, 64, 533-546. [CrossRef]

22. Kolattukudy, P.E. Biopolyester membranes of plants: cutin and suberin. Science 1980, 208, 990-1000. [CrossRef] [PubMed]

23. Pollard, M.; Beisson, F.; Li, Y.; Ohlrogge, J.B. Building lipid barriers: biosynthesis of cutin and suberin. Trends Plant Sci. 2008, 13, 236-246. [CrossRef] [PubMed]

24. Schreiber, L. Transport barriers made of cutin, suberin and associated waxes. Trends Plant Sci. 2010, 15, 546-553. [CrossRef] [PubMed]

25. Xia, Y.; Yu, K.; Gao, Q.M.; Wilson, E.V.; Navarre, D.; Kachroo, P.; Kachroo, A. Acyl CoA binding proteins are required for cuticle formation and plant responses to microbes. Front. Plant Sci. 2012, 3, 224. [CrossRef] [PubMed]

26. Xue, Y.; Xiao, S.; Kim, J.; Lung, S.C.; Chen, L.; Tanner, J.A.; Suh, M.C.; Chye, M.L. Arabidopsis membrane-associated acyl-CoAbinding protein AtACBP1 is involved in stem cuticle formation. J. Exp. Bot. 2014, 18, 5473-5483. [CrossRef]

27. Kim, H.; Choi, D.; Suh, M.C. Cuticle ultrastructure, cuticular lipid composition, and gene expression in hypoxia-stressed Arabidopsis stems and leaves. Plant Cell Rep. 2017, 36, 815-827. [CrossRef]

28. Xie, L.J.; Tan, W.J.; Yang, Y.C.; Tan, Y.F.; Zhou, Y.; Zhou, D.M.; Xiao, S.; Chen, Q.F. Long-chain acyl-CoA synthetase LACS2 contributes to submergence tolerance by modulating cuticle permeability in Arabidopsis. Plants 2020, 9, 262. [CrossRef]

29. Yang, S.U.; Kim, H.; Kim, R.J.; Kim, J.; Suh, M.C. AP2/DREB transcription factor RAP2.4 activates cuticular wax biosynthesis in Arabidopsis leaves under drought. Front. Plant Sci. 2020, 11, 895. [CrossRef]

30. Fahy, E.; Cotter, D.; Sud, M.; Subramaniam, S. Lipid classification, structures and tools. Biochim. Biophys. Acta. 2011, 1811, 637-647. [CrossRef]

31. Furt, F.; Simon-Plas, F.; Mongrand, S. Lipids of the plant plasma membrane. In The Plant Plasma Membrane; Murphy, A.S., Schulz, B., Peer, W., Eds.; Springer: Berlin/Heidelberg, Germany, 2011; Volume 19, pp. 3-30.

32. Ohlrogge, J.B.; Browse, J. Lipid biosynthesis. Plant Cell 1995, 7, 957-970. [CrossRef]

33. Ohlrogge, J.B.; Pollard, M.; Bao, X.; Focke, M.; Girke, T.; Ruuska, S.; Mekhedov, S.; Benning, C. Fatty acid synthesis: from $\mathrm{CO}_{2}$ to functional genomics. Biochem. Soc. Trans. 2000, 28, 567-573. [CrossRef]

34. Ohlrogge, J.B.; Jaworski, J.G. Regulation of fatty acid synthesis. Annu. Rev. Plant Physiol. Plant Mol. Biol. 1997, 48, 109-136. [CrossRef]

35. Harwood, J.L. The synthesis of acyl lipids in plant tissues. Prog. Lipid Res. 1979, 18, 55-86. [CrossRef]

36. Moore, T.S. Phospholipid biosynthesis. Ann. Rev. Plant Physiol. 1982, 33, 235-259. [CrossRef]

37. Vance, J.E.; Vance, D.E. Phospholipid biosynthesis in mammalian cells. Biochem. Cell Biol. 2004, 82, 113-128. [CrossRef] [PubMed]

38. Singer, S.J.; Nicolson, G.L. The fluid mosaic model of the structure of cell membranes. Science 1972, 175, 720-731. [CrossRef]

39. Munnik, T.; Irvine, R.F.; Musgrave, A. Phospholipid signaling in plants. Biochim. Biophys. Acta. 1998, 1389, 222-272. [CrossRef]

40. Hou, Q.; Ufer, G.; Bartels, D. Lipid signaling in plant responses to abiotic stress. Plant Cell Environ. 2016, 39, 1029-1048. [CrossRef] [PubMed] 
41. Xue, H.; Chen, X.; Li, G. Involvement of phospholipid signaling in plant growth and hormone effects. Curr. Opin. Plant Biol. 2007, 10, 483-489. [CrossRef]

42. Lung, S.C.; Chye, M.L. Arabidopsis acyl-CoA-binding proteins regulate the synthesis of lipid signals. New Phytol. 2019, 223, 113-117. [CrossRef] [PubMed]

43. DeWald, D.B.; Torabinejad, J.; Jones, C.A.; Shope, J.C.; Cangelosi, A.R.; Thompson, J.E.; Prestwich, G.D.; Hama, H. Rapid accumulation of phosphatidylinositol 4,5-bisphosphate and inositol 1,4,5-trisphosphate correlates with calcium mobilization in salt-stressed Arabidopsis. Plant Physiol. 2001, 126, 759-769. [CrossRef] [PubMed]

44. de Jong, C.F.; Laxalt, A.M.; Bargmann, B.O.; de Wit, P.J.; Joosten, M.H.; Munnik, T. Phosphatidic acid accumulation is an early response in the Cf-4/Avr4 interaction. Plant J. 2004, 39, 1-12. [CrossRef] [PubMed]

45. Vergnolle, C.; Vaultier, M.N.; Taconnat, L.; Renou, J.P.; Kader, J.C.; Zachowski, A.; Ruelland, E. The cold-induced early activation of phospholipase $\mathrm{C}$ and $\mathrm{D}$ pathways determines the response of two distinct clusters of genes in Arabidopsis cell suspensions. Plant Physiol. 2005, 139, 1217-1233. [CrossRef]

46. Wang, C.R.; Yang, A.F.; Yue, G.D.; Gao, Q.; Yin, H.Y.; Zhang, J.R. Enhanced expression of phospholipase C 1 (ZmPLC1) improves drought tolerance in transgenic maize. Planta 2008, 227, 1127-1140. [CrossRef] [PubMed]

47. Ruelland, E.; Kravets, V.; Derevyanchuk, M.; Martinec, J.; Zachowski, A.; Pokotylo, I. Role of phospholipid signaling in plant environmental responses. Environ. Exp. Bot. 2015, 114, 129-143. [CrossRef]

48. Merrill, A.H.; Stokes, T.H.; Momin, A.; Park, H.; Portz, B.J.; Kelly, S.; Wang, E.; Sullards, M.C.; Wang, M.D. Sphingolipidomics: a valuable tool for understanding the roles of sphingolipids in biology and disease. J. Lipid Res. 2009, 50, S97-S102. [CrossRef]

49. Hannich, J.T.; Umebayashi, K.; Riezman, H. Distribution and functions of sterols and sphingolipids. Cold Spring Harb. Perspect. Biol. 2011, 3, a004762. [CrossRef]

50. Michaelson, L.V.; Napier, J.A.; Molino, D.; Faure, J.D. Plant sphingolipids: their importance in cellular organization and adaption. Biochim. Biophys. Acta. 2016, 1861, 1329-1335. [CrossRef]

51. Markham, J.E.; Li, J.; Cahoon, E.B.; Jaworski, J.G. Separation and identification of major plant sphingolipid classes from leaves. J. Biol. Chem. 2006, 281, 22684-22694. [CrossRef]

52. Ali, U.; Li, H.; Wang, X.; Guo, L. Emerging roles of sphingolipid signaling in plant response to biotic and abiotic stresses. Mol. Plant 2018, 11, 1328-1343. [CrossRef]

53. Schaller, H. The role of sterols in plant growth and development. Prog. Lipid Res. 2003, 42, 163-175. [CrossRef]

54. Dufourc, E.J. The role of phytosterols in plant adaptation to temperature. Plant Signal. Behav. 2008, 3, 133-134. [CrossRef]

55. Simons, K.; Ikonen, E. Functional rafts in cell membranes. Nature 1997, 387, 569-572. [CrossRef]

56. Lingwood, D.; Simons, K. Lipid rafts as a membrane-organizing principle. Science 2010, 327, 46-50. [CrossRef] [PubMed]

57. Tapken, W.; Murphy, A.S. Membrane nanodomains in plants: capturing form, function, and movement. J. Exp. Bot. 2015, 66, 1573-1586. [CrossRef] [PubMed]

58. He, W.S.; Zhu, H.; Chen, Z.Y. Plant sterols: chemical and enzymatic structural modifications and effects on their cholesterollowering activity. J. Agric. Food Chem. 2018, 66, 3047-3062. [CrossRef]

59. Gil, M.; Pontin, M.; Berli, F.; Bottini, R.; Piccoli, P. Metabolism of terpenes in the response of grape (Vitis vinifera L.) leaf tissues to UV-B radiation. Phytochemistry 2012, 77, 89-98. [CrossRef] [PubMed]

60. Barrero-Sicilia, C.; Silvestre, S.; Haslam, R.P.; Michaelson, L.V. Lipid remodelling: unravelling the response to cold stress in Arabidopsis and its extremophile relative Eutrema salsugineum. Plant Sci. 2017, 263, 194-200. [CrossRef]

61. Kumar, M.S.S.; Mawlong, I.; Ali, K.; Tyagi, A. Regulation of phytosterol biosynthetic pathway during drought stress in rice. Plant Physiol. Biochem. 2018, 129, 11-20. [CrossRef]

62. Rogowska, A.; Szekiel, A. The role of sterols in plant response to abiotic stress. Phytochem. Rev. 2020, 19, 1525-1538. [CrossRef]

63. Guidotti, A.; Forchetti, C.M.; Corda, M.G.; Konkel, D.; Bennett, C.D.; Costa, E. Isolation, characterization, and purification to homogeneity of an endogenous polypeptide with agonistic action on benzodiazepine receptors. Proc. Natl. Acad. Sci. USA 1983, 80, 3531-3535. [CrossRef]

64. Nutt, D.J.; Malizia, A.L. New insights into the role of the $\mathrm{GABA}_{\mathrm{A}}$-benzodiazepine receptor in psychiatric disorder. Br. J. Psychiatry 2001, 179, 390-396. [CrossRef] [PubMed]

65. Knudsen, J.; Mandrup, S.; Rasmussen, J.T.; Andreasen, P.H.; Poulsen, F.; Kristiansen, K. The function of acyl-CoA-binding protein (ACBP)/diazepam binding inhibitor (DBI). Mol. Cell. Biochem. 1993, 123, 129-138. [CrossRef]

66. Hills, M.J.; Dann, R.; Lydiate, D.; Sharpe, A. Molecular cloning of a cDNA from Brassica napus L. for a homologue of acyl-CoAbinding protein. Plant Mol. Biol. 1994, 25, 917-920. [CrossRef] [PubMed]

67. Burton, M.; Rose, T.M.; Færgeman, N.J.; Knudsen, J. Evolution of the acyl-CoA binding protein (ACBP). Biochem. J. 2005, 392, 299-307. [CrossRef] [PubMed]

68. Rasmussen, J.T.; Færgeman, N.J.; Kristiansen, K.; Knudsen, J. Acyl-CoA-binding protein (ACBP) can mediate intermembrane acyl-CoA transport and donate acyl-CoA for $\beta$-oxidation and glycerolipid synthesis. Biochem. J. 1994, 299, 165-170. [CrossRef] [PubMed]

69. Rasmussen, J.T.; Rosendal, J.; Knudsen, J. Interaction of acyl-CoA binding protein (ACBP) on processes for which acyl-CoA is a substrate, product or inhibitor. Biochem. J. 1993, 292, 907-913. [CrossRef] 
70. Feddersen, S.; Neergaard, T.B.F.; Knudsen, J.; Færgeman, N.J. Transcriptional regulation of phospholipid biosynthesis is linked to fatty acid metabolism by an acyl-CoA-binding-protein-dependent mechanism in Saccharomyces cerevisiae. Biochem. J. 2007, 407, 219-230. [CrossRef]

71. Elle, I.C.; Simonsen, K.T.; Olsen, L.C.B.; Birck, P.K.; Ehmsen, S.; Tuck, S.; Le, T.T.; Færgeman, N.J. Tissue- and paralogue-specific functions of acyl-CoA-binding proteins in lipid metabolism in Caenorhabditis elegans. Biochem. J. 2011, 437, 231-241. [CrossRef]

72. Shamalnasab, M.; Dhaoui, M.; Thondamal, M.; Harvald, E.B.; Færgeman, N.J.; Aguilaniu, H.; Fabrizio, P. HIF-1-dependent regulation of lifespan in Caenorhabditis elegans by the acyl-CoA-binding protein MAA-1. Aging 2017, 9, 1745-1760. [CrossRef] [PubMed]

73. Li, H.Y.; Chye, M.L. Arabidopsis acyl-CoA-binding protein ACBP2 interacts with an ethylene-responsive element binding protein, AtEBP, via its ankyrin repeats. Plant Mol. Biol. 2004, 54, 233-243. [CrossRef] [PubMed]

74. Li, H.Y.; Xiao, S.; Chye, M.L. Ethylene- and pathogen-inducible Arabidopsis acyl-CoA-binding protein 4 interacts with an ethylene-responsive element binding protein. J. Exp. Bot. 2008, 59, 3997-4006. [CrossRef] [PubMed]

75. Gao, W.; Xiao, S.; Li, H.Y.; Tsao, S.W.; Chye, M.L. Arabidopsis thaliana acyl-CoA-binding protein ACBP2 interacts with a heavymetal-binding farnesylated protein AtFP6. New Phytol. 2009, 181, 89-102. [CrossRef] [PubMed]

76. Gao, W.; Li, H.Y.; Xiao, S.; Chye, M.L. Acyl-CoA-binding protein 2 binds lysophospholipase 2 and lysoPC to promote tolerance to cadmium-induced oxidative stress in transgenic Arabidopsis. Plant J. 2010, 62, 989-1003. [CrossRef] [PubMed]

77. Licausi, F.; Kosmacz, M.; Weits, D.A.; Guintoli, B.; Giorgi, F.M.; Voesenek, L.A.C.J.; Perata, P.; van Dongen, J.T. Oxygen sensing in plants is mediated by an N-end rule pathway for protein destabilization. Nature 2011, 479, 419-422. [CrossRef] [PubMed]

78. Du, Z.Y.; Chen, M.X.; Chen, Q.F.; Xiao, S.; Chye, M.L. Arabidopsis acyl-CoA-binding protein ACBP1 participates in the regulation of seed germination and seedling development. Plant J. 2013, 74, 294-309. [CrossRef]

79. Ye, Z.W.; Chen, Q.F.; Chye, M.L. Arabidopsis thaliana acyl-CoA-binding protein ACBP6 interacts with plasmodesmata-located protein PDLP8. Plant Signal. Behav. 2017, 12, e1359365. [CrossRef]

80. Chen, M.X.; Hu, T.H.; Xue, Y.; Zhu, F.Y.; Du, Z.Y.; Lo, C.; Chye, M.L. Arabidopsis acyl-coenzyme-A-binding protein ACBP1 interacts with AREB1 and mediates salt and osmotic signaling in seed germination and seedling growth. Environ. Exp. Bot. 2018, 156, 130-140. [CrossRef]

81. Lung, S.C.; Liao, P.; Yeung, E.C.; Hsiao, A.S.; Xue, Y.; Chye, M.L. Arabidopsis ACYL-COA-BINDING PROTEIN1 interacts with STEROL C4-METHYL OXIDASE1-2 to modulate gene expression of homeodomain-leucine zipper IV transcription factors. New Phytol. 2018, 218, 183-200. [CrossRef]

82. Miao, R.; Lung, S.C.; Li, X.; Li, X.D.; Chye, M.L. Thermodynamic insights into an interaction between ACYL-CoA-BINDING PROTEIN2 and LYSOPHOSPHOLIPASE2 in Arabidopsis. J. Biol. Chem. 2019, 294, 6214-6226. [CrossRef] [PubMed]

83. Brown, A.P.; Johnson, P.; Rawsthorne, S.; Hills, M.J. Expression and properties of acyl-CoA binding protein from Brassica napus. Plant Physiol. Biochem. 1998, 36, 629-635. [CrossRef]

84. Johnson, P.E.; Rawsthorne, S.; Hills, M.J. Export of acyl chains from plastids isolated from embryos of Brassica napus (L.). Planta 2002, 215, 515-517. [CrossRef]

85. Yurchenko, O.; Singer, S.D.; Nykiforuk, C.L.; Gidda, S.; Muller, R.T.; Moloney, M.M.; Weselake, R.J. Production of a Brassica napus low-molecular mass acyl-coenzyme A-binding protein in Arabidopsis alters the acyl-coenzyme A pool and acyl composition of oil in seeds. Plant Physiol. 2014, 165, 550-560. [CrossRef]

86. Brown, A.P.; Slabas, A.R.; Denton, H. Substrate selectivity of plant and microbial lysophosphatidic acid acyltransferases. Phytochemistry 2002, 61, 493-501. [CrossRef]

87. Chen, Q.F.; Xiao, S.; Chye, M.L. Overexpression of the Arabidopsis 10-kilodalton acyl-coenzyme A-binding protein ACBP6 enhances freezing tolerance. Plant Physiol. 2008, 148, 304-315. [CrossRef]

88. Du, Z.Y.; Xiao, S.; Chen, Q.F.; Chye, M.L. Depletion of the membrane-associated acyl-coenzyme A-binding protein ACBP1 enhances the ability of cold acclimation in Arabidopsis. Plant Physiol. 2010, 152, 1585-1597. [CrossRef] [PubMed]

89. Meng, W.; Su, Y.C.F.; Saunders, R.M.K.; Chye, M.L. The rice acyl-CoA-binding protein gene family: phylogeny, expression and functional analysis. New Phytol. 2011, 189, 1170-1184. [CrossRef]

90. Du, Z.Y.; Chen, M.X.; Chen, Q.F.; Xiao, S.; Chye, M.L. Overexpression of Arabidopsis acyl-CoA-binding protein ACBP2 enhances drought tolerance. Plant Cell Environ. 2013, 36, 300-314. [CrossRef]

91. Meng, W.; Hsiao, A.S.; Gao, C.; Jiang, L.; Chye, M.L. Subcellular localization of rice acyl-CoA-binding proteins (ACBPs) indicates that OsACBP6::GFP is targeted to the peroxisomes. New Phytol. 2014, 203, 469-482. [CrossRef]

92. Qiao, K.; Wang, M.; Takano, T.; Liu, S. Overexpression of Acyl-CoA-Binding Protein 1 (ChACBP1) from saline-alkali-tolerant Chlorella sp. enhances stress tolerance in Arabidopsis. Front. Plant Sci. 2018, 9, 1772. [CrossRef] [PubMed]

93. Panthapulakkal Narayanan, S.; Lung, S.C.; Liao, P.; Lo, C.; Chye, M.L. The overexpression of OsACBP5 protects transgenic rice against necrotrophic, hemibiotrophic and biotrophic pathogens. Sci. Rep. 2020, 10, 14918. [CrossRef]

94. Guo, Z.H.; Pogancev, G.; Meng, W.; Du, Z.Y.; Liao, P.; Zhang, R.; Chye, M.L. The overexpression of rice ACYL-COA-BINDING PROTEIN4 improves salinity tolerance in transgenic rice. Environ. Exp. Bot. 2021, 183, 104349. [CrossRef]

95. Engeseth, N.J.; Pacovsky, R.S.; Newman, T.; Ohlrogge, J.B. Characterization of an acyl-CoA-binding protein from Arabidopsis thaliana. Arch. Biochem. Biophys. 1996, 331, 55-62. [CrossRef] [PubMed]

96. Reddy, A.S.; Ranganathan, B.; Haisler, R.M.; Swize, M.A. A cDNA encoding acyl-CoA-binding protein from cotton. Plant Physiol. 1996, 111, 348 . 
97. Erber, A.; Horstmann, C.; Schobert, C. A cDNA clone for acyl-CoA-binding protein from castor bean. Plant Physiol. 1997, 114, 396.

98. Metzner, M.; Ruecknagel, K.P.; Knudsen, J.; Kuellertz, G.; Mueller-Uri, F.; Diettrich, B. Isolation and characterization of two acyl-CoA-binding proteins from proembryogenic masses of Digitalis lanata Ehrh. Planta 2000, 210, 683-685. [CrossRef]

99. Pastor, S.; Sethumadhavan, K.; Ullah, A.H.J.; Gidda, S.; Cao, H.; Mason, C.; Chapital, D.; Scheffler, B.; Mullen, R.; Dyer, J.; et al. Molecular properties of the class III subfamily of acyl-coenzyme A binding proteins from tung tree (Vernicia fordii). Plant Sci. 2013, 203-204, 79-88. [CrossRef]

100. Takato, H.; Shimidzu, M.; Ashizawa, Y.; Takei, H.; Suzuki, S. An acyl-CoA-binding protein from grape that is induced through ER stress confers morphological changes and disease resistance in Arabidopsis. J. Plant Physiol. 2013, 170, 591-600. [CrossRef]

101. Aznar-Moreno, J.A.; Venegas-Calerón, M.; Du, Z.Y.; Garcés, R.; Tanner, J.A.; Chye, M.L.; Martínez-Force, E.; Salas, J.J. Characterization of a small acyl-CoA-binding protein (ACBP) from Helianthus annuus L. and its binding affinities. Plant Physiol. Biochem. 2016, 102, 141-150. [CrossRef]

102. Amiruddin, N.; Chan, P.L.; Azizi, N.; Morris, P.E.; Chan, K.L.; Ong, P.W.; Rosli, R.; Masura, S.S.; Murphy, D.J.; Sambanthamurthi, R.; et al. Characterization of oil palm acyl-CoA-binding proteins and correlation of their gene expression with oil synthesis. Plant Cell Physiol. 2019, 61, 735-747. [CrossRef] [PubMed]

103. Zhu, J.; Li, W.; Zhou, Y.; Pei, L.; Liu, J.; Xia, X.; Che, R.; Li, H. Molecular characterization, expression and functional analysis of acyl-CoA-binding protein gene family in maize (Zea mays). BMC Plant Biol. 2021, 21, 94. [CrossRef] [PubMed]

104. Azlan, N.S.; Guo, Z.H.; Yung, W.S.; Wang, Z.; Lam, H.M.; Lung, S.C.; Chye, M.L. In silico analysis of acyl-CoA-binding protein expression in soybean. Front. Plant Sci. 2021, 12, 646938. [CrossRef]

105. Raboanatahiry, N.H.; Yin, Y.; Chen, L.; Li, M. Genome-wide identification and phylogenic analysis of kelch motif containing ACBP in Brassica napus. BMC Genom. 2015, 16, 512. [CrossRef]

106. Chye, M.L.; Huang, B.Q.; Zee, S.Y. Isolation of a gene encoding Arabidopsis membrane associated acyl-CoA binding protein and immunolocalization of its gene product. Plant J. 1999, 18, 205-214. [CrossRef]

107. Li, H.Y.; Chye, M.L. Membrane localization of Arabidopsis acyl-CoA-binding protein ACBP2. Plant Mol. Biol. 2003, 51, 483-492. [CrossRef] [PubMed]

108. Leung, K.C.; Li, H.Y.; Xiao, S.; Tse, M.H.; Chye, M.L. Arabidopsis ACBP3 is an extracellularly targeted acyl-CoA-binding protein. Planta 2006, 223, 871-881. [CrossRef]

109. Xiao, S.; Li, H.Y.; Zhang, J.P.; Chan, S.W.; Chye, M.L. Arabidopsis acyl-CoA-binding proteins ACBP4 and ACBP5 are subcellularly localized to the cytosol and ACBP4 depletion affects membrane lipid composition. Plant Mol. Biol. 2008, 68, 571-583. [CrossRef]

110. Meng, W.; Chye, M.L. Rice acyl-CoA-binding proteins OsACBP4 and OsACBP5 are differentially localized in the endoplasmic reticulum of transgenic Arabidopsis. Plant Signal. Behav. 2014, 9, e29544. [CrossRef]

111. Liao, P.; Leung, K.P.; Lung, S.C.; Panthapulakkal Narayanan, S.; Jiang, L.; Chye, M.L. Subcellular localization of rice acyl-CoAbinding proteins ACBP4 and ACBP5 supports their non-redundant roles in lipid metabolism. Front. Plant Sci. 2020, 11, 331. [CrossRef]

112. Xiao, S.; Gao, W.; Chen, Q.F.; Chan, S.W.; Zheng, S.X.; Ma, J.; Wang, M.; Welti, R.; Chye, M.L. Overexpression of Arabidopsis acyl-CoA binding protein ACBP3 promotes starvation-induced and age-dependent leaf senescence. Plant Cell 2010, 22, 1463-1482. [CrossRef]

113. Leung, K.C.; Li, H.Y.; Mishra, G.; Chye, M.L. ACBP4 and ACBP5, novel Arabidopsis acyl-CoA-binding proteins with kelch motifs that bind oleoyl-CoA. Plant Mol. Biol. 2004, 55, 297-309. [CrossRef]

114. Chye, M.L.; Li, H.Y.; Yung, M.H. Single amino acid substitutions at the acyl-CoA-binding domain interrupt ${ }^{14}[\mathrm{C}] p a l m i t o y l-C o A$ binding of ACBP2, an Arabidopsis acyl-CoA-binding protein with ankyrin repeats. Plant Mol. Biol. 2000, 44, 711-721. [CrossRef]

115. Xiao, S.; Chen, Q.F.; Chye, M.L. Light-regulated Arabidopsis ACBP4 and ACBP5 encode cytosolic acyl-CoA-binding-proteins that bind phosphatidylcholine and oleoyl-CoA ester. Plant Physiol. Biochem. 2009, 47, 926-933. [CrossRef] [PubMed]

116. Chen, Q.F.; Xiao, S.; Qi, W.; Mishra, G.; Ma, J.; Wang, M.; Chye, M.L. The Arabidopsis acbp1acbp2 double mutant lacking acyl-CoA-binding proteins ACBP1 and ACBP2 is embryo lethal. New Phytol. 2010, 186, 843-855. [CrossRef] [PubMed]

117. Xiao, S.; Chye, M.L. The Arabidopsis thaliana ACBP3 regulates leaf senescence by modulating phospholipid metabolism and ATG8 stability. Autophagy 2010, 6, 802-804. [CrossRef]

118. Aznar-Moreno, J.A.; Venegas-Calerón, M.; Du, Z.Y.; Garcés, R.; Tanner, J.A.; Chye, M.L.; Martínez-Force, E.; Salas, J.J. Characterization and function of a sunflower (Helianthus annus L.) Class II acyl-CoA-binding protein. Plant Sci. 2020, 300, 110630. [CrossRef] [PubMed]

119. Lung, S.C.; Liao, P.; Yeung, E.C.; Hsiao, A.S.; Xue, Y.; Chye, M.L. Acyl-CoA-binding protein ACBP1 modulates sterol synthesis during embryogenesis. Plant Physiol. 2017, 174, 1420-1435. [CrossRef]

120. Xiao, S.; Chye, M.L. Arabidopsis ACBP1 overexpressors are Pb(II)-tolerant and accumulate Pb(II). Plant Signal. Behav. 2008, 3 , 693-695. [CrossRef] [PubMed]

121. Xiao, S.; Chye, M.L. Overexpression of Arabidopsis acyl-CoA-binding protein 3 enhances NPR1-dependent plant resistance to Pseudomonas syringae pv. tomato DC3000. Plant Physiol. 2011, 156, 2069-2081. [CrossRef]

122. Zheng, S.X.; Xiao, S.; Chye, M.L. The gene encoding Arabidopsis acyl-CoA-binding protein 3 is pathogen-inducible and subject to circadian regulation. J. Exp. Bot. 2012, 63, 2985-3000. [CrossRef] [PubMed]

123. Liao, P.; Chen, Q.F.; Chye, M.L. Transgenic Arabidopsis flowers overexpressing acyl-CoA-binding protein ACBP6 are freezing tolerant. Plant Cell Physiol. 2014, 55, 1055-1071. [CrossRef] 
124. Du, Z.Y.; Chen, M.X.; Chen, Q.F.; Gu, J.D.; Chye, M.L. Expression of Arabidopsis acyl-CoA binding proteins AtACBP1 and AtACBP4 confers $\mathrm{Pb}(\mathrm{II})$ accumulation in Brassica juncea roots. Plant Cell Environ. 2015, 38, 101-117. [CrossRef] [PubMed]

125. Ye, Z.W.; Lung, S.C.; Hu, T.H.; Chen, Q.F.; Suen, Y.L.; Wang, M.; Hoffmann-Benning, S.; Yeung, E.; Chye, M.L. Arabidopsis acyl-CoA-binding protein ACBP6 localizes in the phloem and affects jasmonate composition. Plant Mol. Biol. 2016, 92, 717-730. [CrossRef]

126. Hu, T.H.; Lung, S.C.; Ye, Z.W.; Chye, M.L. Depletion of Arabidopsis ACYL-COA-BINDING PROTEIN3 affects fatty acid composition in the phloem. Front. Plant Sci. 2018, 9, 2. [CrossRef] [PubMed]

127. Panthapulakkal Narayanan, S.; Liao, P.; Taylor, P.W.J.; Lo, C.; Chye, M.L. Overexpression of a monocot acyl-CoA-binding protein confers broad-spectrum pathogen protection in a dicot. Proteomics 2019, 19, 1800368. [CrossRef]

128. Zhou, Y.; Tan, W.J.; Xie, L.J.; Qi, H.; Yang, Y.C.; Huang, L.P.; Lai, Y.X.; Tan, Y.F.; Zhou, D.M.; Yu, L.J.; et al. Polyunsaturated linolenoyl-CoA modulates ERF-VII-mediated hypoxia signaling in Arabidopsis. J. Integr. Plant Biol. 2020, 62, 330-348. [CrossRef]

129. Hsiao, A.S.; Haslam, R.P.; Michaelson, L.V.; Liao, P.; Chen, Q.F.; Sooriyaarachchi, S.; Mowbray, S.L.; Napier, J.A.; Tanner, J.A.; Chye, M.L. Arabidopsis cytosolic acyl-CoA-binding proteins ACBP4, ACBP5 and ACBP6 have overlapping but distinct roles in seed development. Biosci. Rep. 2015, 34, e00165. [CrossRef]

130. Guo, Z.H.; Haslam, R.P.; Michaelson, L.V.; Yeung, E.C.; Lung, S.C.; Napier, J.A.; Chye, M.L. The overexpression of rice ACYLCoA-BINDING PROTEIN2 increases grain size and bran oil content in transgenic rice. Plant J. 2019, 100, 1132-1147. [CrossRef]

131. Guo, Z.H.; Ye, Z.W.; Haslam, R.P.; Michaelson, L.V.; Napier, J.A.; Chye, M.L. Arabidopsis cytosolic acyl-CoA binding proteins function in determining seed oil content. Plant Direct 2019, 3, e00182. [CrossRef]

132. Hsiao, A.S.; Yeung, E.C.; Ye, Z.W.; Chye, M.L. The Arabidopsis cytosolic acyl-CoA-binding proteins play combinatory roles in pollen development. Plant Cell Physiol. 2015, 56, 322-333. [CrossRef] [PubMed]

133. Chye, M.L. Arabidopsis cDNA encoding a membrane-associated protein with an acyl-CoA binding domain. Plant Mol. Biol. 1998, 38, 827-838. [CrossRef] [PubMed]

134. Schmidt, R.R.; Fulda, M.; Paul, M.V.; Anders, M.; Plum, F.; Weits, D.A.; Kosmacz, M.; Larson, T.R.; Graham, I.A.; Beemster, G.T.S.; et al. Low-oxygen response is triggered by an ATP-dependent shift in oleoyl-CoA in Arabidopsis. Proc. Natl. Acad. Sci. USA 2018, 115, E12101-E12110. [CrossRef] [PubMed]

135. Xiao, S.; Gao, W.; Chen, Q.F.; Ramalingam, S.; Chye, M.L. Overexpression of membrane-associated acyl-CoA-binding protein ACBP1 enhances lead tolerance in Arabidopsis. Plant J. 2008, 54, 141-151. [CrossRef] [PubMed]

136. Xie, L.J.; Yu, L.J.; Chen, Q.F.; Wang, F.Z.; Huang, L.; Xia, F.N.; Zhu, T.R.; Wu, J.X.; Yin, J.; Liao, B.; et al. Arabidopsis acyl-CoAbinding protein ACBP3 participates in plant response to hypoxia by modulating very-long-chain fatty acid metabolism. Plant J. 2015, 81, 53-67. [CrossRef] [PubMed]

137. Xie, L.J.; Chen, Q.F.; Chen, M.X.; Yu, L.J.; Huang, L.; Chen, L.; Wang, F.Z.; Xia, F.N.; Zhu, T.R.; Wu, J.X.; et al. Unsaturation of very long-chain ceramides protects plant from hypoxia induced damages by modulating ethylene signaling in Arabidopsis. PLoS Genet. 2015, 11, e1005143. [CrossRef]

138. Du, Z.Y.; Arias, T.; Meng, W.; Chye, M.L. Plant acyl-CoA-binding proteins: an emerging family involved in plant development and stress responses. Prog. Lipid Res. 2016, 63, 165-181. [CrossRef]

139. Gibbs, D.J.; Lee, S.C.; Isa, N.M.; Gramuglia, S.; Fukao, T.; Bassel, G.W.; Correia, C.S.; Corbineau, F.; Theodolou, F.L.; Bailey-Serres, J.; et al. Homeostatic response to hypoxia is regulated by the N-end rule pathway in plants. Nature 2011, 479, 415-418. [CrossRef]

140. Lee, S.C.; Luan, S. ABA signal transduction at the crossroad of biotic and abiotic stress responses. Plant Cell Environ. 2012, 35, 53-60. [CrossRef]

141. Christmann, A.; Weiler, E.W.; Steudle, E.; Grill, E. A hydraulic signal in root-to-shoot signaling of water shortage. Plant J. 2007, 52, 167-174. [CrossRef]

142. Raghavendra, A.S.; Gonugunta, V.K.; Christmann, A.; Grill, E. ABA perception and signaling. Trends Plant Sci. $2010,15,395-401$. [CrossRef] [PubMed]

143. Wu, Y.; Kuzma, J.; Maréchal, E.; Graeff, R.; Lee, H.C.; Foster, R.; Chua, N.H. Abscisic acid signaling through cyclic ADP-ribose in plants. Science 1997, 278, 2126-2130. [CrossRef] [PubMed]

144. Jacob, T.; Ritchie, S.; Assmann, S.M.; Gilroy, S. Abscisic acid signal transduction in guard cells is mediated by phospholipase D activity. Proc. Natl. Acad. Sci. USA 1999, 96, 12192-12197. [CrossRef] [PubMed]

145. Lemtiri-Chlieh, F.; MacRobbie, E.A.C.; Brearley, C.A. Inositol hexakisphosphate is a physiological signal regulating the $\mathrm{K}^{+}$-inward rectifying conductance in guard cells. Proc. Natl. Acad. Sci. USA 2000, 97, 8687-8692. [CrossRef]

146. Pei, Z.M.; Murata, Y.; Benning, G.; Thomine, S.; Klüsener, B.; Allen, G.J.; Grill, E.; Schroeder, J.I. Calcium channels activated by hydrogen peroxide mediate abscisic acid signaling in guard cells. Nature 2000, 406, 731-734. [CrossRef]

147. Allen, G.J.; Chu, S.P.; Harrington, C.L.; Schumacher, K.; Hoffmann, T.; Tang, Y.Y.; Grill, E.; Schroeder, J.I. A defined range of guard cell calcium oscillation parameters encodes stomatal movements. Nature 2001, 411, 1053-1057. [CrossRef]

148. Ng, C.K.; Carr, K.; McAinsh, M.R.; Powell, B.; Hetherington, A.M. Drought-induced guard cell signal transduction involves sphingosine-1-phosphate. Nature 2001, 410, 596-599. [CrossRef]

149. Scrase-Field, S.A.M.G.; Knight, M.R. Calcium: just a chemical switch? Curr. Opin. Plant Biol. 2003, 6, 500-506. [CrossRef]

150. Zhang, W.; Qin, C.; Zhao, J.; Wang, X. Phospholipase D $\alpha 1$-derived phosphatidic acid interacts with ABI1 phosphatase $2 \mathrm{C}$ and regulates abscisic acid signaling. Proc. Natl. Acad. Sci. USA 2004, 101, 9508-9513. [CrossRef]

151. Luan, S. The CBL-CIPK network in plant calcium signaling. Trends Plant Sci. 2009, 14, 37-42. [CrossRef] 
152. Peters, C.; Li, M.; Narasimhan, R.; Roth, M.; Welti, R.; Wang, X. Nonspecific phospholipase C NPC4 promotes responses to abscisic acid and tolerance to hyperosmotic stress in Arabidopsis. Plant Cell 2010, 22, 2642-2659. [CrossRef] [PubMed]

153. Belamkar, V.; Weeks, N.T.; Bharti, A.K.; Farmer, A.D.; Graham, M.A.; Cannon, S.B. Comprehensive characterization and RNA-Seq profiling of the HD-Zip transcription factor family in soybean (Glycine max) during dehydration and salt stress. BMC Genom. 2014, 15, 950. [CrossRef] [PubMed]

154. Ashraf, M. Some important physiological selection criteria for salt tolerance in plants. Flora 2004, 199, 361-376. [CrossRef]

155. Yang, Y.; Guo, Y. Elucidating the molecular mechanisms mediating plant salt-stress responses. New Phytol. 2018, 217, 523-539. [CrossRef] [PubMed]

156. Hasegawa, P.M.; Bressan, R.A.; Zhu, J.K.; Bohnert, H.J. Plant cellular and molecular responses to high salinity. Annu. Rev. Plant Physiol. Plant Mol. Biol. 2000, 51, 463-499. [CrossRef] [PubMed]

157. Munns, R.; Tester, M. Mechanisms of salinity tolerance. Annu. Rev. Plant Biol. 2008, 59, 651-681. [CrossRef]

158. Shen, B.; Jensen, R.G.; Bohnert, H.J. Increased resistance to oxidative stress in transgenic plants by targeting mannitol biosynthesis to chloroplasts. Plant Physiol. 1997, 113, 1177-1183. [CrossRef]

159. Tsugane, K.; Kobayashi, K.; Niwa, Y.; Ohba, Y.; Wada, K.; Kobayashi, H. A recessive Arabidopsis mutant that grows photoautotrophically under salt stress shows enhanced active oxygen detoxification. Plant Cell 1999, 11, 1195-1206. [CrossRef]

160. Hong, Z.; Lakkineni, K.; Zhang, Z.; Verma, D.P.S. Removal of feedback inhibition of delta(1)-pyrroline-5-carboxylate synthetase results in increased proline accumulation and protection of plants from osmotic stress. Plant Physiol. 2000, 122, 1129-1136. [CrossRef]

161. Zhu, J.; Fu, X.; Koo, Y.D.; Zhu, J.K.; Jenney, F.E.; Adams, M.W.; Zhu, Y.; Shi, H.; Yun, D.J.; Hasegawa, P.M.; et al. An enhancer mutant of Arabidopsis salt overly sensitive 3 mediates both ion homeostasis and the oxidative stress response. Mol. Cell. Biol. 2007, 27, 5214-5224. [CrossRef]

162. Hazman, M.; Hause, B.; Eiche, E.; Nick, P.; Riemann, M. Increased tolerance to salt stress in OPDA-deficient rice ALLENE OXIDE CYCLASE mutants is linked to an increased ROS-scavenging activity. J. Exp. Bot. 2015, 66, 3339-3352. [CrossRef] [PubMed]

163. Li, J.; Liu, J.; Wang, G.; Cha, J.Y.; Li, G.; Chen, S.; Li, Z.; Guo, J.; Zhang, C.; Yang, Y.; et al. A chaperone function of NO CATALASE ACTIVITY1 is required to maintain catalase activity and for multiple stress responses in Arabidopsis. Plant Cell 2015, 27, 908-925. [CrossRef]

164. Testerink, C.; Munnik, T. Phosphatidic acid: a multifunctional stress signaling lipid in plants. Trends Plant Sci. 2005, 10, 368-375. [CrossRef] [PubMed]

165. Testerink, C.; Munnik, T. Molecular, cellular, and physiological responses to phosphatidic acid formation in plants. J. Exp. Bot. 2011, 62, 2349-2361. [CrossRef] [PubMed]

166. Liu, A.; Xiao, Z.; Wang, Z.; Lam, H.M.; Chye, M.L. Galactolipid and phospholipid profile and proteome alterations in soybean leaves at the onset of salt stress. Front. Plant Sci. 2021, 12, 644408. [CrossRef]

167. Yu, L.; Nie, J.; Cao, C.; Jin, Y.; Yan, M.; Wang, F.; Liu, J.; Xiao, Y.; Liang, Y.; Zhang, W. Phosphatidic acid mediates salt stress response by regulation of MPK6 in Arabidopsis thaliana. New Phytol. 2010, 188, 762-773. [CrossRef]

168. Shi, H.; Quintero, F.J.; Pardo, J.M.; Zhu, J.K. The putative plasma membrane $\mathrm{Na}^{+} / \mathrm{H}^{+}$antiporter SOS1 controls long-distance Na+ transport in plants. Plant Cell 2002, 14, 465-477. [CrossRef]

169. Qiu, Q.S.; Guo, Y.; Dietrich, M.A.; Schumaker, K.S.; Zhu, J.K. Regulation of SOS1, a plasma membrane $\mathrm{Na}^{+} / \mathrm{H}^{+}$exchanger in Arabidopsis thaliana, by SOS2 and SOS3. Proc. Natl. Acad. Sci. USA 2002, 99, 8436-8441. [CrossRef]

170. Shabala, L.; Cuin, T.A.; Newman, I.A.; Shabala, S. Salinity-induced ion flux patterns from the excised roots of Arabidopsis sos mutants. Planta 2005, 222, 1041-1050. [CrossRef]

171. Bargmann, B.O.R.; Laxalt, A.M.; ter Riet, B.; van Schooten, B.; Merquiol, E.; Testerink, C.; Haring, M.A.; Bartels, D.; Munnik, T. Multiple PLDs required for high salinity and water deficit tolerance in plants. Plant Cell Physiol. 2009, 50, 78-89. [CrossRef]

172. Gasch, P.; Fundinger, M.; Müller, J.T.; Lee, T.; Bailey-Serres, J.; Mustropha, A. Redundant ERF-VII transcription factors bind to an evolutionarily conserved cis-motif to regulate hypoxia-responsive gene expression in Arabidopsis. Plant Cell 2016, $28,160-180$. [CrossRef] [PubMed]

173. Xie, L.J.; Zhou, Y.; Chen, Q.F.; Xiao, S. New insights into the role of lipids in plant hypoxia responses. Prog. Lipid Res. 2021, 81, 101072. [CrossRef] [PubMed]

174. Yuan, L.B.; Dai, Y.S.; Xie, L.J.; Yu, L.J.; Zhou, Y.; Lai, Y.X.; Yang, Y.C.; Xu, L.; Chen, Q.F.; Xiao, S. Jasmonate regulates plant responses to postsubmergence reoxygenation through transcriptional activation of antioxidant synthesis. Plant Physiol. 2017, 173, 1864-1880. [CrossRef] [PubMed]

175. Farmer, E.E.; Ryan, C.A. Octadecanoid precursors of jasmonic acid activate the synthesis of wound-inducible proteinase inhibitors. Plant Cell 1992, 4, 129-134. [CrossRef] [PubMed]

176. Roberts, K. Potential awareness of plants. Nature 1992, 360, 14-15. [CrossRef]

177. Meindl, T.; Boller, T.; Felix, G. The plant wound hormone systemin binds with the N-terminal part to its receptor but needs the C-terminal part to activate it. Plant Cell 1998, 10, 1561-1570. [CrossRef]

178. Scheer, J.M.; Ryan, C.A. A 160-kD Systemin receptor on the surface of Lycopersicon peruvianum suspension-cultured cells. Plant Cell 1999, 11, 1525-1535. [CrossRef]

179. Creelman, R.A.; Mullet, J.E. Biosynthesis and action of jasmonates in plants. Annu. Rev. Plant Physiol. 1997, 48, 355-381. [CrossRef] 
180. Yurchenko, O.P.; Weselake, R.J. Involvement of low molecular mass soluble acyl-CoA-binding protein in seed oil biosynthesis. New Biotechnol. 2011, 28, 97-109. [CrossRef]

181. Valitova, J.N.; Sulkarnayeva, A.G.; Minibayeva, F.V. Plant sterols: diversity, biosynthesis, and physiological functions. Biochemistry 2016, 81, 819-834. [CrossRef]

182. Nolan, T.; Chen, J.; Yin, Y. Cross-talk of brassinosteroid signaling in controlling growth and stress responses. Biochem. J. 2017, 474, 2641-2661. [CrossRef]

183. Pokotylo, I.; Kravets, V.; Martinec, J.; Ruelland, E. The phosphatidic acid paradox: too many actions for one molecule class? Lessons from plants. Prog. Lipid Res. 2018, 71, 43-53. [CrossRef] 